\title{
Neurologic complications in kidney transplant recipients
}

\author{
Piotr C. Piotrowski ${ }^{1,2}$, Anna Lutkowska², Alexander Tsibulski², Marek Karczewski³, Paweł P. Jagodziński \\ ${ }^{1}$ Department of Experimental and Clinical Neuropathology, Mossakowski Medical Research Centre, Polish Academy of Sciences, \\ Warszawa, ${ }^{2}$ Department of Biochemistry and Molecular Biology, Poznań University of Medical Sciences, Poznań, ${ }^{3}$ Department \\ of Transplantology, General, Vascular and Plastic Surgery, Clinical Hospital of Poznan University of Medical Sciences, Poznań, Poland
}

\begin{abstract}
Transplantology experiences continuous growth and kidney transplantation is the most frequently transplanted solid organ. Metabolic, cardiovascular, infectious or kidney function-related aspects are widely recognised and are of key interest for transplant doctors. Neurological complications seen in these patients, although known, are less covered in the literature. According to some reports, neurologic symptoms are experienced by almost 9 per 10 transplant recipients. The intensity, severity and type of abnormalities may vary, and most frequently the complications seem to be associated with a direct or indirect effect of immunosuppressive medications, including their direct effect on cells, on blood vessels, and susceptibility to infections. Increasing age of transplant recipients and relaxation of transplantation eligibility criteria enriches the population with patients already compromised, with a higher present risk of stroke, neuropathy, malignancy etc. Research on and introduction to clinical practice of new agents like belatacept, proteasome inhibitors, or modified release formulations of tacrolimus, changes the picture and type of abnormalities within the nervous or neuromuscular system but does not eliminate them. Thus, it seems justified to remind the society of the whole array of neurologic complications they can see in their practice despite advances in the field.
\end{abstract}

Key words: kidney transplantation, immunosuppression, neurotoxicity, PTLD, PRES, opportunistic infections, CNS.

\section{Introduction}

Kidney is the most widely transplanted solid organ associated with high survival rates, which makes renal transplant a growing area of interest in the modern era of nephrology. One of the crucial drawbacks in successful renal transplantation is allograft rejection. Survival rates among transplant recipients have greatly improved due to better understanding of transplant biology and more effective immunosuppressive agents. In the US, less than $30 \%$ of the approximately 615,000 patients that were diagnosed with end-stage renal disease (ESRD) have received a kidney transplant and more than 100,000 patients are on the waiting list for a donor kidney [189]. In some other countries, like Spain or the Netherlands, more than $50 \%$ of ESRD patients are treated with kidney transplantation [19]. Current immunosuppressive protocols tend to prevent acute rejection of renal allografts better than the old ones despite lower doses of immunosuppressive drugs used nowadays in general. Post-transplant immune monitoring and optimization of the immunosuppressive therapy using non-invasive biomarkers can effectively predict impending graft rejection and may spare the need for renal biopsy. However, drug 
toxicity and the unfavourable effects of long-term immunosuppression are associated with significant morbidity and mortality.

The goals of pharmacotherapy in kidney transplantation are to prevent graft rejection, reduce morbidity, and prevent complications. Immunosuppressant drug classes include calcineurin inhibitors (CNIs), corticosteroids, antimetabolites, mammalian target of rapamycin (mTOR) inhibitors, and other immunosuppressants like depleting antibodies (Table I). Transplant recipients are maintained on an immunosuppression regimen based on 1-3 drugs. There is a number of regimens which can be used, including pre-transplantation induction therapy and simple postoperative maintenance therapy; the choice of regimen depends on the patient's profile, training and experience of the transplantation centre, local standards, and reimbursement status of drugs. According to the report of the United States Renal Data System (USRDS) [207], the majority (90\% in 2012) of kidney transplant recipients received antibody induction. While the use of anti-IL-2R (interleukin-2 receptor) antagonists has fallen in the US from a peak of $41 \%$ in 2002 to $25 \%$ in 2012 , the use of T-cell depleting agents continues to increase, reaching 65\% in 2012 [207] and this trend may continue due to weak data supporting the use of IL-2R antagonists $[86,227,228]$. However, in Europe, IL2RA induction was more widely used than rabbit antithymocyte globulin ( $\mathrm{rATG}$ ) or other depleting agents [145]. Nearly all transplant recipients in 2012 received a calcineurin inhibitor and an anti-metabolite as components of their initial immunosuppressive regimen. $92 \%$ of these patients were prescribed tacrolimus (Tac) as their first-line CNI, and mycophenolate mofetil (MMF) has almost completely replaced azathioprine (Aza) as the anti-metabolite of choice. Use of mTOR inhibitors, both initially and at one year following transplantation, has declined to $2 \%$ and $4 \%$,

Table I. Immunosuppressive agents used in organ transplant recipients*

\begin{tabular}{|c|c|c|}
\hline Induction & Maintenance treatment & Treatment of rejections \\
\hline Polyclonal and monoclonal antibodies & Corticosteroids & Corticosteroids \\
\hline Polyclonal (ATG) & Prednisone & Polyclonal and monoclonal antibodies \\
\hline $\begin{array}{c}\text { Monoclonal anti-CD3 (OKT3/Muromonab), } \\
\text { withdrawn }\end{array}$ & Calcineurin inhibitors & $\begin{array}{l}\text { Reversible } 265 \text { proteasome inhibitor } \\
\text { (Bortezomib) }\end{array}$ \\
\hline Monoclonal anti CD-52 (Alemtuzumab) & Cyclosporine, Tacrolimus & Anti-C5 antibody (Eculizumab) \\
\hline Monoclonal anti-CD20 (Rituximab) & $\begin{array}{c}\text { Anti-metabolites/Anti-proliferative } \\
\text { agents }\end{array}$ & \\
\hline $\begin{array}{l}\text { Interleukin-2 receptor antagonists, } \\
\text { monoclonal anti-CD25 }\end{array}$ & Azathioprine & \\
\hline Basiliximab & $\begin{array}{l}\text { Mycophenolate mofetil, } \\
\text { Mycophenolic acid }\end{array}$ & \\
\hline Daclizumab, withdrawn & Mizoribine & \\
\hline Corticosteroids & Leflunomide & \\
\hline \multirow[t]{2}{*}{ Methylprednisolone } & $m$-TOR inhibitors & \\
\hline & Sirolimus, Everolimus & \\
\hline \multicolumn{3}{|c|}{ Co-stimulation blocker } \\
\hline \multicolumn{3}{|c|}{ Belatacept (fusion protein) } \\
\hline \multicolumn{3}{|c|}{ Protein kinase C inhibitor } \\
\hline \multicolumn{3}{|c|}{ Sotrastaurin } \\
\hline \multicolumn{3}{|c|}{$J A K 3$ inhibitors } \\
\hline \multicolumn{3}{|c|}{ Tofacitinib } \\
\hline \multicolumn{3}{|c|}{ Alkylating agents } \\
\hline & Cyclophosphamide & \\
\hline
\end{tabular}


respectively, in 2012, while steroid use seems to be stabilizing at about 67\% [207].

Immunosuppressive agents are known to show numerous side effects, including the ones affecting the nervous system directly or indirectly. Majority of solid organ transplant recipients experience neurologic complications after transplantation, and only minority of cases (e.g. femoral neuropathy, stroke) can be attributed to the surgery or the pre-existing comorbidities (e.g. atherosclerosis, hypertension, diabetes) alone [67,160,212]. Immunosuppressive medications, can induce direct or indirect neurotoxicity or increase the risk of central nervous system (CNS) infections and tumours. Neurotoxic effects can manifest either in the central or in the peripheral nervous system (PNS). Immunosuppressive medications used in transplantation that have most frequently been associated with neurologic complications include cyclosporine (CSA), tacrolimus (Tac, FK506), corticosteroids, and muromonab (OKT3) [53,63, 197,220,222,223]. In addition, frequent disturbances of hepatic and kidney metabolism may appreciably prolong the half-life of drugs and increase their plasma levels. The use of various medications interfering with cytochrome CYP3A function may alter the levels of Tac and CSA [130] and affect their safety profile.

Apart from a potentially detrimental effect of immunosuppression, an impaired kidney function itself can be a cause of adverse neurologic outcomes. For example, changes in creatinine, eGFR, serum nitrogen, CRP, 1,25- $(\mathrm{OH})_{2} \mathrm{D}_{3}$, intact parathyroid hormone (iPTH), phosphorus were found to correlate with psychological and cognitive disorders in patients with treated chronic kidney disease [108].

Neurologic complications following kidney transplantation are more common compared to the general population and the incidence of neurologic alterations is reported in up to $85 \%$ of recipients $[21,71,177,230]$. Somewhat contrary to this prevalent opinion, in a relatively small retrospective analysis of magnetic resonance imaging of transplant recipients in Charleston, SC Medical University, frequency of posterior reversible encephalopathy syndrome, and both acute and chronic lesions/changes in brain did not differ significantly between patients before and after kidney transplantation [26]. They can be classified as several core groups: infection, drug toxicity, structural pathology (stroke, cancer, vasculitis), and metabolic abnormalities including those caused by graft dysfunction [230].
In a retrospective study, it was reported that most frequent neurologic complications following renal transplantation were focal neurologic deficits (20\%), acute confusion (16\%), seizures (15\%) and headache (13\%) [21]. An increased frequency of stroke in kidney allograft recipients is attributable to the progression of pre-existing vasculopathy and hypertension $[1,173]$. Kidney transplantation surgery is also associated with an increased incidence of femoral and lumbosacral plexopathy [56].

This review, although focusing on kidney transplantation is generally applicable to all solid organs as the medications used in e.g. heart or liver transplantology are merely the same although some differences exist when it comes to doses, regimes, and underlying diseases. In the review we analyse firstly the neurotoxicity from selected therapeutic agents perspective, and then we discuss selected most relevant neurotoxicities. Because of volume limitations of the paper we have not been able to cover all relevant topics, including e.g. neurologic complications related directly to an impaired kidney function, linked to use of other medications used in this population of patients, we have barely mentioned importance of genetics/epigenetics behind increased vulnerability to immunosuppression, psychological impact of the transplantation itself, available treatment of the complications etc. We also acknowledge availability of a number of review papers on this subject in contemporary literature. However, we hope that our approach will provide a unique perspective, and by encompassing recent advances in the field, will be a valuable summary for clinicians and scientists interested in this slightly overlooked aspect of transplantology.

\section{Neurotoxicity of immunosuppressive drugs}

\section{Calcineurin inhibitors}

Cyclosporine is an 11 amino acids polypeptide of fungal origin and a pro-drug, which has been a keystone of immunosuppression in transplantation for four decades. This agent is used for induction and maintenance of immunosuppression. Tacrolimus is a macrolide antibiotic and a calcineurin inhibitor with 2-3 times the potency of cyclosporine. Tac can be used at lower doses than cyclosporine, but its adverse effects include renal dysfunction, neurotoxicity (tremor, insomnia, and paraesthesia of the 
extremities), and new-onset diabetes. Tacrolimus has essentially replaced cyclosporine as the CNI of choice, because of a claimed lower rejection rate including decreased steroid-resistant rejection, and according to some studies, superior graft survival $[6,135,172]$. Some other studies do not support the superiority of Tac vs CsA, though $[12,129]$ and it may partly depend on CYP3A5 (6986 A>G, rs776746) polymorphism [117]. Currently, $80-90 \%$ of patients receive Tac after renal transplantation instead of cyclosporine, and this change has persisted for the past 10-15 years.

CsA and Tac induce immunosuppression by inhibiting the first phase of T-cell activation by binding to immunophilins. The immunosuppressive, and possibly neurotoxic, action of both CSA and Tac is exerted through inhibition of the calcium calmodulin-dependent protein phosphatase, calcineurin [82]. Calcineurin is essential for the dephosphorylation of the nuclear factor of activation of T cells (NFAT) which is responsible for activation of T-cells. The first phase of T-cell activation causes transcriptional activation of interleukin (IL)-2, IL-3, IL-4, tumour necrosis factor (TNF) alpha, and interferon gamma that allow T-cells to progress from the G0- to G1-phase [195]. Thus, CSA and Tac both work to inhibit IL-2, which is a critical link in the proliferation of helper $T$ cells. These agents bind to a group of proteins called immunophilins, divided into CsA-binding cyclophilins and FK-binding proteins, to form complexes that then bind to and inhibit the activated calcineurin phosphatase. The tacrolimus: FKBP12 active complex inhibits calcineurin with greater potency than the corresponding cyclosporine complex [83].

Calcineurin and immunophilins have a widespread expression in the central and peripheral nervous systems, but the exact mechanism of CsAor tacrolimus-induced neurotoxicity is not yet well understood. Protein dephosphorylation by calcineurin may play an important role in neuronal signal transduction due to its ability to regulate the activity of ion channels, glutamate release, and synaptic plasticity [235]. Calcineurin has been shown to regulate the activity of $N$-methyl- $D$-aspartate (NMDA) receptor channels by both altering their ion gating properties and promoting desensitization in cultured hippocampal neurons, which has been ascribed to the enhanced release of glutamate by the presynaptic cells $[142,185,213]$. Since NMDA receptors are highly permeable to $\mathrm{Ca}^{2+}$, the influx of extracellular $\mathrm{Ca}^{2+}$ is considered to be the primary event responsible for glutamate toxicity and neuronal cell death [115].

Mechanisms underlying calcineurin inhibitors neurotoxicity may be related to: (1) upregulation of endothelin receptors $A$ and $B$ and stimulation of endothelin 1 synthesis; (2) damage of the bloodbrain barrier (BBB); (3) alterations in the mitochondrial function; (4) interaction with neuromodulatory systems and (5) vascular toxicity. Circulating endothelin, produced in excess in the presence of CNIs can affect the cerebral vascular smooth muscle and could promote systemic hypertension [147,190,203]; the endothelin-mediated effect is also promoted by CsA-dependent upregulation of endothelin receptors $A$ and $B[141,238]$. On the other hand, if endothelial integrity is disrupted, CsA and Tac could gain access to astrocytes. Under such conditions, local ischemia and consequent white matter oedema could show transient alterations observed in cases of acute hypertensive encephalopathy [143] or in PRES (Posterior Reversible Encephalopathy Syndrome). CsA and Tac are highly lipophilic and are bounded in plasma, especially to low-density lipoprotein (LDL). Since LDL receptors are also expressed on the cell membrane of astrocytes at the blood-brain barrier, increased uptake of these drugs can lead to damage of the BBB as well as the white matter. The vasoconstriction induced by CNI may cause microvascular damage and disrupt the blood-brain barrier [4,177]. In case reports of patients treated with relatively high doses of CsA, published by Shbarou et al. [182], lesions in the cerebral white matter associated with abnormally elevated cerebral blood flow velocities on transcranial Doppler ultrasound and abnormal vascular appearance on magnetic resonance angiography were seen. The authors reported the changes as resembling brain lesions seen in pre-eclampsia. CNI can lead to decrease the expression of p-glycoprotein in the brain endothelial cell and cause dysfunction of the blood-brain barrier leading to vasogenic oedema [221]. CsA and Tac increased proinflammatory cytokines and endothelial activation markers in cultured murine endothelial and vascular smooth muscle cells, and in ex vivo cultures of murine aortas through TLR4 and with no significant role of calcineurin. In TLR4 knockout mice CNIs were unable to induce inflammation and endothelial activation in aortas. The CNI-induced-TLR4 activity lead to increased $\mathrm{O}_{2}(-) /$ ROS production and NF- $\kappa \mathrm{B}$-regulated 
synthesis of proinflammatory factors in cultured as well as aortic endothelial and VSMCs [170]. Part of CSA and Tac toxicity may arise from interference with mitochondrial functions [93], such as decrease of mitochondrial energy production and the subsequent activation of anaerobic glycolysis, impaired cellular calcium buffering, activation of proteases and phospholipases, activation of nitric oxide synthase (NOS) and generation of free radicals, leading to either apoptotic or necrotic cell death [180]. CsA and Tac appear to affect neuronal transmission in specific circuits via the following mechanisms: (1) inhibition of the gamma-amino butyric acid (GABA) system that amplifies excitatory response and limits inhibitory response, which may be the mechanism behind the increased seizure activity in transplant recipients; (2) neuronal serotonin depletion, which may explain depression and tremor; (3) glutaminergic NMDA receptor inhibition, suggesting a possible role for psychotic features. In a recent study it was shown in a model of chronic CSA or Tac microinjections into medial prefrontal cortex in rats that calcineurin-inhibition-induced depressive-like behaviour is mediated by blockade of the mTOR signalling pathway and can be reversed by NMDA [237]. Influence on NMDA-dependent signalling through potentiating presynaptic and postsynaptic NMDAR activity in the spinal cord may increase glutamate-mediated nociceptive input and be responsible for calcineurin inhibitor-induced pain syndrome (CIPS) linked to CsA or Tac use [42,45].

Table II. Neurologic side-effects of calcineurin inhibitors

\begin{tabular}{|l|}
\hline Tremors \\
\hline Sleep disturbances, insomnia \\
\hline Paraesthesia, pain syndrome, polyneuropathy \\
\hline Mood disturbances \\
\hline $\begin{array}{l}\text { Mental status changes: confusion, disorientation, paranoia, } \\
\text { hallucinations, lethargy, apathy, depression, irritability, } \\
\text { aggression }\end{array}$ \\
\hline Leukoencephalopathy, toxic encephalopathy \\
\hline Seizures \\
\hline $\begin{array}{l}\text { Visual disturbances: hemianopsia, cortical blindness, } \\
\text { blurred vision }\end{array}$ \\
\hline $\begin{array}{l}\text { Motor symptoms: paraplegia, quadriplegia, paresis, } \\
\text { dystonia }\end{array}$ \\
\hline $\begin{array}{l}\text { Speech or language disturbances: akinetic mutism, aphasia, } \\
\text { slurred speech }\end{array}$ \\
\hline Other movement disorders: asterixis \\
\hline
\end{tabular}

It was shown that nerve excitability testing demonstrated abnormal nerve function in CNI-treated patients, reflecting nerve membrane depolarization [13]. This can translate into the reduced threshold for action potential generation and easier development of neuropathic symptoms, including paraesthesia and cramps [132]. More severe depolarization may lead to sodium channel inactivation and reduce the size of the action potential, leading to sensory loss and fatigue [105].

Of note, treatment with CsA significantly reduced plasma concentrations of adrenocorticotropic hormone (ACTH), cortisol, and noradrenaline whereas adrenaline levels and state of anxiety remained unaffected [8]. This effect was shown to attenuate stress-responsiveness in animal studies [99].

Neurologic complications have been reported to occur in $10 \%$ to $28 \%$ of the patients treated with CsA $[77,200]$. Common complications include tremor, headache, and less frequently, PRES [53,223] (Table II). Mild symptoms in patients treated with CsA are frequent, and encompass tremor, neuralgia, and peripheral neuropathy. Severe symptoms affect up to $5 \%$ of transplant recipients such as psychoses, hallucinations, blindness, seizures, cerebellar ataxia and motor weakness $[24,40,53,97,111,156,204]$. Hypocholesterolemia and hypomagnesemia were suggested as possible precipitating factors for CSA neurotoxicity, however CSA neurotoxicity may be seen in patients with normal cholesterol and magnesium as well [53]. Symptoms typically improve by discontinuation, dosage reduction, or substitution with Tac [223]. Further reports indicate less toxicity associated with the oral route of administration [222]. Epileptiform EEG changes and frank seizures have been described in patients treated with CsA [7,231]. In a small number of patients, myalgia and myopathy have been linked to treatment with CSA. Interference with the mitochondrial function was suggested as the causative mechanism [33]. Use of CNIs in clinical practice in transplantology has significantly changed over the last 20 years. Introduction of microemulsion formulation of cyclosporine, CNI minimization strategies, trough levels monitoring, and introduction of modified release preparations of tacrolimus can be expected to decrease the frequency and severity of neurotoxicity in the longer term [193]. Although in a 12-month large randomized prospective study, no difference in neurotoxicity was seen between standard-dose CsA and low-dose CsA or low-dose Tac groups, it has to be noted that the trough levels of CsA 
were not that much different in that study (approx. 150 vs. $100 \mathrm{ng} / \mathrm{ml}$ ) with levels not exceeding $250 \mathrm{ng} / \mathrm{ml}$ for most of the study duration in the standard dosing group [64]. Noteworthy, there was no significant difference in the prevalence of brain abnormalities in early compared with late post-transplant periods when exposure to $\mathrm{Cl}$ is tapered, and the authors concluded that abnormalities seen in brain MR in kidney transplant recipients are likely not predominantly linked to CNI toxicity [26].

Neurologic complications may be more severe while on Tac than on CSA $[120,136]$, particularly in children $[73,126]$, and it was also reported in liver transplant patients (The US Multicenter FK506 Liver Study Group). Some studies show complications related to Tac are less frequent, $5.4 \%$ versus $25 \%$ than to CsA [63] while in other publications on solid organ transplantations frequency of neurologic complications is higher in Tac than in CsA-treated groups $[126,205]$. Complications typically occur in the early post-transplant period, when higher doses and intravenous formulations are used [63]. Common neurologic complications of Tac include tremor, encephalopathy, headache, and seizures [63,220] (Table II). Mild symptoms include tremor, insomnia, nightmares, headache, vertigo, dysesthesia, photophobia and mood disturbances. Severe manifestations include akinetic mutism, seizures, cortical blindness, focal deficits, psychosis and encephalopathy [52]. The most serious complication is PRES, presenting with nausea, hematemesis, headache, loss of vision, seizures and altered consciousness [149], associated with subcortical and deep white matter changes $[74,94]$. The spontaneous resolution of the syndrome is probably associated with the spontaneous reduction in hemodynamic disorders. A rare but severe side effect of Tac can be peripheral neuropathy. About $0.003 \%$ of patients developed severe multifocal demyelinating sensorimotor polyneuropathy 2-10 weeks after the start of treatment with Tac, though similar changes can also be observed with CsA [224]. In another report, a late onset severe chronic inflammatory demyelinating polyradiculoneuropathy was diagnosed 10 years after Tac initiation, and resolved after Tac withdrawal [165].

The treatment of immunosuppressive neurotoxicity consists of correction of electrolyte imbalance and hypertension, immunosuppressant dose reduction and switching from cyclosporine to tacrolimus or vice versa, if necessary $[109,196,233]$. Use of combinations, such as CNI plus mycophenolate or mTOR inhibitor, enables lower doses of cyclosporine or tacrolimus to be used without weakening the immunosuppressive effect [124]. These approaches lead in most cases to the disappearance of the symptoms and the reversal of neuroimaging anomalies [27].

\section{Corticosteroids}

Corticosteroids are used for induction and maintenance immunosuppression, as well as against acute rejection. These agents prevent production of cytokines and vasoactive substances, including IL-1, IL-2, IL-6, tumor necrosis factor- $\alpha$, chemokines, prostaglandins, major histocompatibility class II and proteases. Corticosteroids act as agonists of glucocorticoid receptors, but at higher doses, have receptor-independent effects. Corticosteroids have three principal mechanisms of action: 1) inhibit the synthesis of inflammatory proteins blocking NF- $\kappa B$, 2) induce the expression of anti-inflammatory proteins by IkB and MAPK phosphatase I, and 3) inhibit 5 -lipoxygenase and cyclooxygenase-2 [44]. Some of the observed effects of corticosteroids depend on the increase in the adrenergic effects of catecholamines and of the synthesis of epinephrine from norepinephrine [65].

Glucocorticoids and, to a lesser extent, mineralocorticoids cross the blood-brain barrier to access corticosteroid receptors within the CNS [206]. There are two major classes of corticosteroid receptors: mineralocorticoid receptors and glucocorticoid receptors [167].

Glucocorticoid receptors in the cytoplasm are in an inactive complex with heat shock proteins. The binding of corticosteroids to the glucocorticoid receptors dissociates heat shock proteins from the glucocorticoid receptors. Active corticosteroid-glucocorticoid receptor complexes migrate to the nucleus and dimerize on palindromic DNA sequences in many genes. The binding of glucocorticoid receptors in the promoter region of the target genes can lead to either induction or suppression of gene transcripts.

The most common corticosteroids used in transplantation are oral prednisolone/prednisone and intravenous methylprednisolone. Their role in maintenance immunosuppression is still under investigation because of severe side effects during longterm use. These agents are metabolized by the liver and excreted by kidneys as inactive metabolites. Drug interactions with P450 inhibitors and inducers are common. The neurologic complications of corticosteroids are reversible with a reduction and/ 
or withdrawal of their intravenous administration [166]. Common neurological complications linked to steroids are myopathies of skeletal and respiratory muscles and psychiatric disorders [32,55,208]. Psychiatric disorders include confusion, mood disturbances, manic states, psychotic reactions, anxiety, sleeplessness, reduced concentration, cognitive impairment. Steroid-induced psychosis is rare, but complications such as schizophrenic syndromes, affective disorders or delirium can also occur due to steroids use $[57,150,214,226]$. It was suggested that $50 \%$ of patients treated with medium to high doses of steroids for more than 3 weeks develop a proximal myopathy starting in the hip muscles. Steroid myopathy usually resolves slowly and it takes 2 to 8 months following discontinuation [37,47].

High-dosage treatment with corticosteroids and neuromuscular blocking agents may lead to the development of critical illness myopathy $[36,107]$. Myopathy usually improves gradually with dosage reduction or discontinuation of therapy. Epidural lipomatosis is a rare complication of steroid therapy; spinal compression and radiculopathy have been reported [70].

It has been proposed that cognitive dysfunction caused by corticosteroids may be a result of a combination of impaired hippocampal neurogenesis and subcortical white matter dysfunction [57].

Risk factors predisposing for neuropsychiatric side effects of corticosteroids include a daily dose of prednisone greater than $40 \mathrm{mg}$, damaged bloodbrain barrier, hypoalbuminemia, and prior history of steroid-related psychosis or mania [218].

Prolonged use of steroids may also indirectly lead to numerous non-specific neurologic complications, including those related to opportunistic infections, osteoporosis, diabetes mellitus, obesity, elevated blood pressure etc. $[44,60]$.

\section{Polyclonal and monoclonal antibodies}

Biologic agents are polyclonal and monoclonal antibodies that are frequently used in transplantation for induction immunosuppression or treatment of rejection. The three antibodies used for induction therapy are the lymphocyte-depleting agents: (1) antithymocyte globulin (ATG), (2) basiliximab, and (3) alemtuzumab (Table I). However, alemtuzumab has not been granted market approval for use in transplantations and has not been endorsed by recent Cochrane review due to insufficient and inconclusive data $[9,87]$. Historically, immunosuppressant selection was based solely on efficacy for the prevention of rejection. In the current era of transplantation, it is a common practice in the transplant community to select induction therapy based on risk-benefit considerations for each patient.

Polyclonal antibodies induce lysis of lymphocytes. Antithymocyte globulin rabbit acts against human T-cell surface antigens and depletes CD4 lymphocytes. In addition to T-cell depletion, it induces B-cell apoptosis, interferes with dendritic cell function, modulates adhesion molecules and chemokine receptors and induces regulatory T-cells. Administration of ATG can induce a cytokine-release syndrome, which includes fever, chills and sometimes hypotension and pulmonary oedema, and may mimic neurotoxicity reported after OKT3 use. ATG has many adverse effects (fever, thrombocytopenia, leukopenia, haemolysis, respiratory distress, serum sickness, and anaphylaxis), but some of them may be ameliorated with steroids. It is indicated for prophylaxis and treatment of renal transplant acute rejection in conjunction with concomitant immunosuppression. In comparison with basiliximab it causes a higher rate of infections including opportunistic infections [9,20,87,106,199].

The monoclonal antibodies used (mostly in clinical research except for basiliximab) in transplant patients include anti-CD3 antibody (OKT3, muromonab), anti-CD25 antibody (basiliximab and daclizumab), anti-CD20 antibody (rituximab) and antiCD52 antibody (alemtuzumab) (Table I). Except for OKT3, their administration to transplant patients is associated with a very low prevalence of neurologic adverse effects.

\section{Basiliximab}

Basiliximab is an IL-2R antagonist indicated for prophylaxis of kidney transplant rejection and is used as induction treatment. Its use has not been linked to specific neurotoxicities and has not been shown to increase occurrence of malignancies or opportunistic infections $[20,106]$.

\section{Alemtuzumab}

Alemtuzumab is a humanized recombinant monoclonal antibody against CD52 which is present on T-cells, B-cells, NK cells and to a lesser extent on monocytes. 
As with ATG, alemtuzumab infusion can be followed by a cytokine-release syndrome [225], however it is much milder than with ATG. It is used off-label as part of various induction regimens in patients undergoing kidney transplantation. The use of alemtuzumab as induction immunosuppression for renal transplantation introduces the possibility of long-term Tac monotherapy, avoiding maintenance with both corticosteroids and MMF. Renal transplantation with alemtuzumab induction followed by Tac monotherapy leads to good graft and patient outcomes, with no major differences detected compared with basiliximab induction and tacrolimus/mycophenolate mofetil maintenance at one year. Higher frequency of opportunistic infections comparing to basiliximab has been suggested $[87,106,158]$, which may translate into the corresponding risk of neurologic complications.

\section{OKT3}

OKT3 is a murine monoclonal antibody targeted against the CD3 adhesion molecule on lymphocytes. It was most frequently used in the treatment of rejection, and it was associated with aseptic meningitis, encephalopathy and seizures [197]. OKT3 caused release of systemic proinflammatory cytokines in CSF, which are responsible for the flu-like syndrome and may be involved in the pathogenesis of the cerebral oedema [3]. Approximately 5\% to $10 \%$ of patients treated with OKT3 developed an acute aseptic meningeal syndrome associated with aseptic meningitis presenting within 72 hours of its administration [90]. Diffuse encephalopathy was rarely seen with coma, seizures, psychosis and brain oedema. The encephalopathy may take up to 2 weeks to resolve. OKT3 is rarely associated with neurologic complications because of its reduced neurotoxicity and its current limited clinical indications. Its use was contraindicated in patients with underlying neurologic problems such as seizures. The product has been withdrawn from the market [22].

\section{Rituximab}

Rituximab is a chimeric anti-CD20 monoclonal antibody which acts through depletion of $B$ cells [18]. It has not been approved for use in renal transplantation [169] but its use has been endorsed for specific subpopulations of organ transplant recipients by the international transplantology society expressed in national guidelines $[39,159,229]$ e.g. for $A B O$ blood group incompatible transplantation, for post-transplant lymphoproliferative disorder, HLA antibody incompatible renal transplantation and for treatment of acute rejections. It has been postulated that rituximab may prevent development of chronic antibody mediated rejection [18]. Regarding its toxicity, the drug can cause e.g. cytokine release syndrome, progressive multifocal leukoencephalopathy infusion-associated hypotension, cardiovascular disorders and infections [169]. Cases of PRES linked to rituximab administration were also reported [25].

\section{Belatacept}

Belatacept is a selective T-cell costimulation blocker. It comprises of a recombinant extracellular domain of human cytotoxic T lymphocyte antigen-4 (CTLA-4) and a fragment of a modified Fc portion of human IgG1. The drug binds to CD 80/86 ligands of antigen-stimulating cells and thereby inhibits the CD-28-mediated T-cell costimulation. T-cells activation requires two signals of which the first signal is mediated by the interaction of major histocompatibility complex (MHC): T cell receptor (TCR) and the second is mediated by the costimulatory molecules. The costimulatory molecules CD80/86 ligands in the antigen presenting cells bind to CD28 of the T-cells to induce the immunological response. The costimulatory molecules CD28:CD80/86 interaction is also essential for clonal proliferation of cytotoxic $T$ cells which play a main role in the graft rejection [112].

Belatacept has been approved for use in combination therapy to prevent renal graft rejection in patients who are Epstein-Barr virus seropositive. Despite some advantages over calcineurin inhibitor-based regimens it bears a risk of post-transplant lymphoproliferative disorder (PTLD), a rapidly progressing and often lethal malignancy. The occurrence of PTLD, particularly PTLD involving the central nervous system was noted in 0-4\% of belatacept-treated patients in clinical trials. Belatacept has also potential to induce progressive multifocal leukoencephalopathy $[23,68,106,121]$.

\section{mTor inhibitors}

Mammalian target of rapamycin (mTOR) inhibitors inhibit T-cell activation and proliferation. Unlike calcineurin inhibitors, sirolimus and everolimus inhibit the second phase of T-cell activation [83]. 
The second phase involves signal transduction and clonal proliferation of T-cells. These agents inhibit interleukin-induced proliferation of T-cells resulting in the cell cycle arrest in the late G1-phase, which prevents progression to the S-phase [80]. Mammalian target of rapamycin (mTOR) is a serine/threonine kinase, integrating multiple signals such as nutrition, oxygen supply, and growth factors [38]. mTOR inhibitors (sirolimus and everolimus) need to bind to the 12-kD immunophilin FK-506-binding protein in order to block the serine/threonine kinase activity of the mTOR/raptor/GbetaL complex [85]. Two TOR proteins have been identified - TOR1 and TOR2 and both everolimus and sirolimus were long thought to act almost only through inhibition of TOR1 complex (TORC1) [239]. However, there has been increasing evidence that the additional hydroxyethyl group at the $C(40)$ of the everolimus is linked to not only different tissue and subcellular distribution, but also to different affinities to active drug transporters and drug-metabolizing enzymes, and interaction with TORC2 than sirolimus [103]. It was suggested that everolimus, but not sirolimus, distributes to brain mitochondria and stimulates mitochondrial oxidation in the brain and contrary to sirolimus, everolimus counteracts CsA-related negative effects in the rat brain energy state $[102,178,179]$. In contrast to sirolimus, everolimus was shown not to affect cyclosporine concentrations in blood and brain tissue but it reduced cyclosporine concentrations in brain mitochondria by $65 \%$ [178].

Sirolimus and everolimus have shown their efficacy in kidney transplantation in a variety of immunosuppression regimes, but their wide use has been limited by relative high discontinuation rates and safety profile. Their most important adverse effects are thrombocytopenia, leukopenia, hypercholesterolemia, stomatitis, diarrhoea, and, interstitial pneumonitis [131]. In a long-term retrospective analysis of 10 prospective randomized trials in kidney transplantation it was shown that the efficacy of de novo use of mTOR inhibitor is similar to antimetabolites in kidney transplant recipients receiving calcineurin inhibitor. Patients on mTOR inhibitor benefited from the lower CMV infection rate, but the overall safety profile was unfavourable, showing higher treatment discontinuation rates and higher incidence of proteinuria [54]. In heart transplant recipients patients switched from CNI to mTORi had a higher creatinine clearance but also significantly higher occurrence of adverse effects, which included skin diseases, gastrointestinal side effects, bone marrow suppression, and infections [163]. Also, when compared with mycophenolate as part of the combination with CNI in kidney transplantation, mTOR-I showed no particular superiority to mycophenolate, and instead mTOR-I had an increased risk of graft loss when combined with $\mathrm{CNI}$, even when combined with a reduced dose of $\mathrm{CNI}$. In this retrospective analysis of 4930 patients treated with mTOR-it had a higher risk of new-onset diabetes mellitus, dyslipidemia, proteinuria, peripheral oedema, thrombocytopenia and lymphocele, but a lower risk of CMV infection, malignancy and leukopenia. Neurotoxicity was not reported [234].

Neurotoxicity with mTOR inhibitors is relatively low, however PRES associated with mTOR inhibitors was reported [134,162,202]. Sirolimus rarely causes neurotoxicity since it can alter cell metabolism of astrocytes, thus resulting in similar neurotoxicity as experienced by Tac and CSA (tremor, confusion, agitation and headache) [175]. For everolimus rare adverse effects are dizziness, hypoesthesia, paraesthesia, somnolence, and tremor [11]. Bilateral optic neuropathy was also reported [202]. As mentioned earlier, mTOR intermediates depression-like symptoms which may lead to corresponding psychiatric abnormalities during mTOR inhibitors use $[2,237]$, although scarce evidence exists that mTOR inhibitors may have a more favourable profile than $\mathrm{CNIs}$ in this respect [111]. In a small study, no difference between CNIs and everolimus was shown in terms of negative impact on the cognitive function in heart transplant recipients. About $40 \%$ of subjects had cognitive impairment, defined as performance at least 1.5 standard deviations below normative mean in one or several cognitive domains in that population [35].

\section{Other immunosuppressants}

Apart from a variety of off-label agents used occasionally or in clinical trials in transplantology, there are two other important subgroups of medications which belong to standard of care in solid organ transplantations. The first group comprises agents inhibiting synthesis of nucleotides - purine synthesis inhibitors - mycophenolate and pyrimidine synthesis inhibitors - leflunomide. The second group comprises old drugs - so-called antimetabo- 
lites: azathioprine and cyclophosphamide [171]. From this selection, mycophenolate derivatives (mofetil or sodium salt) are most frequently used. Mycophenolate inhibits enzyme - inosine monophosphate dehydrogenase (IMPDH) required for guanosine synthesis and suppresses de novo purine synthesis in lymphocytes, thus inhibiting their proliferation [127]. Mycophenolate impairs B and T-cell proliferation, sparing other rapidly dividing cells due to the presence of guanosine salvage pathways in other cells. This agent is frequently used in regimens containing a calcineurin inhibitor and corticosteroids for prevention of renal allograft rejection [171]. Mycophenolate has been shown to decrease prevalence of acute cellular rejection compared with azathioprine and prevalence of chronic rejection $[6,154]$. The prescribing information for MMF reports psychiatric disorders - common - agitation, confusional state, depression, anxiety, thinking abnormal, insomnia, and nervous system disorders - common - convulsion, hypertonia, tremor, somnolence, myasthenic syndrome, dizziness, headache, paraesthesia, dysgeusia as adverse reactions possible or probable related to MMF. Cases of JC virus related PML have also been reported. It is also possible that the rate of infections is increased in relation to mycophenolate use [137]. A case study reported a 64-year-old woman who developed a severe depressive disorder after the start of therapy [59]. However, it is generally believed that mycophenolate is not causing neurotoxicity [11].

According to Cochrane analysis, mycophenolic acid was superior azathioprine to AZA for improvement of graft survival and prevention of acute rejection after kidney transplantation. However it was noted that these benefits must be weighed against potential harms. The available evidence on safety outcomes is limited and inconsistent [215]. Azathioprine (Aza), a disease-modifying antirheumatic drug (DMARD), was also employed in renal transplantation to prevent graft rejection however due to reported higher efficacy of mycophenolate, its use in organ transplantations has been declining significantly. Its anti-proliferative properties are less selective than those of MMF $[66,210]$. Azathioprine antagonizes purine metabolism and inhibits synthesis of DNA, RNA, and proteins. It may decrease proliferation of immune cells, which results in lower autoimmune activity $[6,156]$. Azathioprine has been clearly identified as having potential to increase the neuromuscular blockade produced by depolarising agents such as succinylcholine and can reduce the blockade produced by non-depolarising agents such as tubocurarine [15]. An increased risk of infections and cases of PML were also reported for AZA [15]. Very rare cases of psychiatric complications of AZA were reported [31] and they comprised a complex picture of behavioural changes, forgetfulness, confusion, memory loss and communication difficulty, obsessive-compulsive disorder and panic attacks [31,209].

Neither leflunomide nor cyclophosphamide has been used as part of standard immunosuppression after organ and specifically kidney transplantation [101,159]. However, Johannes et al. [216] have published recently a systematic report on cyclophosphamide-based treatment of acute antibody-mediated rejection showing a positive effect of combined regimen (with plasmapheresis and i.v. immunoglobulins) proven with modern diagnostic measures. Cyclophosphamide has been linked with multiple toxicities. According to Summary of Product Characteristics [51], apart from an increased risk of infections, the following side effects are known or suspected to be related to cyclophosphamide a) psychiatric disorders (very rare confusional state), b) nervous system disorders (uncommon - peripheral neuropathy, polyneuropathy, neuralgia, convulsion, dizziness, dysgeusia, hypogeusia, paraesthesia, general neurotoxicity, unknown frequency - PRES, encephalopathy). Also, vision disorders, hearing disorders and muscle symptoms were noted.

Regarding other agents reported in the context of immunosuppression in organ transplantology, it is worth mentioning relatively new agents - bortezomib and eculizumab [106, 159]. Bortezomib (BTZ) is a proteasome inhibitor and an antineoplastic drug that reversibly inhibits mammalian $26 \mathrm{~S}$ proteasome and interacts with the nuclear factor kappa B (NFkB) system, thus leading to cytoplasmic aggregate accumulation and cell cycle arrest in cancer cells [128]. It is also known to induce neurotoxicity in neuronal cells by several mechanisms that lead to apoptosis [176]. BTZ has been shown to induce peripheral neuropathy characterized by neuropathic pain in a stocking-and-glove distribution and by paraesthesias in distal extremities of limbs, mainly due to unmyelinated and thin myelinated sensory fibers impairment (C and A $\delta$ fibers, respectively) [128]. Eculizumab is a fully humanized monoclonal antibody directed against the $\mathrm{C} 5$ component of the complement cas- 
cade. There have been inconclusive data on its efficacy in kidney transplantation although some results have been encouraging PTT 2016 [96,114,236]. Eculizumab is known to increase the risk of infections, including increases in the patient's susceptibility to meningococcal infection (Neisseria meningitidis) [17]. According to the Summary of Product Characteristics [62], headache has been another typical adverse reaction of eculizumab. Other potential adverse reactions include: psychiatric disorders insomnia, depression, mood disorder, anxiety, abnormal dreams, sleep disorders; neurologic disorders dizziness, dysgeusia, tremor, paraesthesia, syncope; other - vision disturbances. tinnitus and vertigo, musculoskeletal symptoms [62].

\section{Neurologic complications of kidney transplantation}

\section{Ischemic stroke}

Ischemic strokes are relatively common in heart and kidney transplant recipients. Stroke may occur in $8 \%$ of renal transplant recipients and may be facilitated by hypertension, diabetes and accelerated atherosclerosis, which may be acquired during dialysis or after transplantation [160]. Apart from immunosuppressive treatment, ischemic strokes may be related to the surgical procedure of transplantation, complications typical for surgery (e.g. bacterial infections, anaesthesia-related negative outcomes, bleeding etc.), presence of bacterial endocarditis and vasoinvasive fungal CNS infections, hypercoag ulable states, accelerated atherosclerosis, vasculitis and cardiac arrhythmias after transplantation [160]. While aetiology of strokes in the transplant recipient population is shifted toward perioperative and infectious causes, in medium- and long-term survivors accelerated atherosclerosis after transplantation $[48,146]$ will affect cerebrovascular circulation increasing the risk of stroke [140]. In heart and liver allograft recipients, strokes occur early after transplantation and they tend to occur late after kidney transplantation. In kidney transplant recipients, age over 40 and diabetes were found to be major risk factors for cerebrovascular disease [4].

Ischemic strokes after kidney transplantation are frequently related to atherosclerosis [144]. A significant reduction in stroke incidence has been reported in diabetic patients receiving simultaneous kidney and pancreas transplantation [140]. Concomitant control of the main risk factors (cholesterol, glycaemia and hypertension) is critical as is preventive treatment with antiplatelet agents like aspirin. Cyclosporine, mTOR inhibitors, and to a lesser extent, Tac, may cause hypercholesterolemia, accelerating cerebrovascular disease, especially in patients with prolonged survival [174]. Also, patients who converted from CNI to mTOR inhibitor have a substantially greater risk of e.g. anaemia, hyperlipidaemia and hypercholesterolemia [116]. According to a recent paper published by Simha et al. [186], sirolimus is associated with elevation in PCSK9 levels, which is not associated with sirolimus-induced hypercholesterolemia. This suggests an independent pathway for mTOR-inhibitors-induced hypercholesterolemia, as PSCK9 plays a major regulatory role in cholesterol homeostasis, mainly by reducing LDL receptor (LDLR) levels on the plasma membrane. Reduced LDLR levels result in decreased metabolism of LDL-particles, which could lead to hypercholesterolemia [76]. Substituting CsA with Tac may reduce cholesterol levels [198]. On the other hand, it has been postulated that mTOR inhibitors may offer a cardioprotective effect as in experimental settings delayed progression of atherosclerosis is observed consistent with evidence from heart transplant patients where coronary artery intimal thickening and the incidence of cardiac allograft vasculopathy are reduced with everolimus versus cyclosporine therapy. Earlier data exist as well showing that mTOR inhibitors may improve arterial stiffness, which precedes cardiovascular (CV) events, and may reduce ventricular remodelling and decrease left ventricular mass through an anti-fibrotic effect [89]. Thus, cardiovascular /hypercholesterolemia-related effects of mTOR inhibitors may not necessarily contribute to CV-dependent neurologic complications seen during their use. Clinical data support this hypothesis. In a retrospective analysis, patients receiving SRL after liver transplantation had no increased risk of coronary artery disease or cardiovascular accidents (CAD/CVA) as compared with patients maintained on a calcineurin inhibitor [217].

Stroke is more common after kidney transplantation, while encephalopathy, seizures and CPM (central pontine myelinolysis) are characteristic of liver transplantation. In kidney transplant patients, stroke is the most common neurologic complication, whereas cerebral infarction and bleeding are more typical after heart transplantation. Kidney allograft recipients frequently develop post-transplant poly- 
cythaemia (17\% of patients) and hypercoagulability, which may increase the risk of stroke $[5,100]$. The risk for aneurismal subarachnoid haemorrhage is increased 10-fold in kidney allograft recipients transplanted for polycystic kidney disease [219]. Diabetic nephropathy as a cause of pre-transplant kidney failure also increases the risk of post-transplant intracranial haemorrhage [219] and it can be anticipated that the same consequence follows from diabetes related to use of immunosuppressants. Calcineurin inhibitors and steroids are best known to induce post-transplant diabetes, with a higher risk of this complication seen with tacrolimus. In a retrospective analysis of kidney transplant recipients, post-transplantation diabetes mellitus occurred more frequently in patients receiving a cadaver organ compared with a living donor organ and in those receiving tacrolimus therapy vs cyclosporine therapy [29,61]. However, also mTOR inhibitors were associated with an increased risk of new-onset diabetes after transplantation (NODAT) [29].

\section{Encephalopathy}

Metabolic encephalopathy is common among transplant recipients; the aetiology is as variable as in non-transplant patients, commonly including electrolyte and changes in glucose levels. Patients with pre-existing diabetes are sensitive to treatment with steroids, in addition Tac may precipitate diabetic ketoacidosis. Abrupt, inadvertent steroid discontinuation may also cause a disturbance of consciousness. Patients with a severe systemic infection without CNS involvement typically develop sepsis-related encephalopathy $[30,91]$. Delayed graft function in orthotopic liver and kidney transplantation is associated with hepatic and uremic encephalopathy, respectively [91].

Common causes of encephalopathy include neurotoxicity from non-immunosuppressive drugs, various metabolic derangements, CNS or systemic infections, and stroke. Immunosuppressant-related encephalopathy has been also described with e.g. CsA, Tac, OKT3 $[16,43,88,110,164,194]$, and as mentioned earlier - rituximab, belatacept and cyclophosphamide. Although neurotoxicity of mTOR inhibitors is relatively low, they can induce PRES in kidney transplantation patients $[134,162,202]$. Neurotoxicity is usually associated with higher serum concentrations of immunosuppressants, but may also become apparent at serum levels within the therapeutic range. Common adverse signs are tremor, headache and cerebellar or extrapyramidal signs [157].

Neurotoxicity of CNIs is clinically indistinguishable and classical neuroimaging findings are indistinguishable from PRES in eclampsia or hypertensive encephalopathy $[88,110,191]$. It is not fully understood why posterior circulation is usually more severely affected, but this has been attributed to the less extensive sympathetic vascular innervation posteriorly. Clinically, PRES commonly presents with akinetic mutism, visual symptoms, occipital seizures, and overall impairment of consciousness [16]. Most commonly, Tac or CSA-related PRES presents within the first month after transplantation, but rarely occurs more than a year later $[43,164]$.

\section{Neuromuscular complications}

Femoral neuropathy and meralgia paresthetica have been reported in renal and liver transplantation, while phrenic nerve injury is seen in the setting of heart and lung transplantation $[14,161,183]$. Lumbosacral plexopathy may be associated with retroperitoneal bleeding or iliac artery pseudoaneurysms [119]. Peripheral mononeuritis and polyneuritis may also occur. An acute femoral neuropathy can develop in $2 \%$ of the patients as a result of perioperative nerve compression by retractors or nerve ischemia. Patients complain of weakness in the thigh and pain or sensory deficits on the thigh and inner calf. Most patients have an excellent chance of recovery [181,212].

Peripheral toxicity occurs weeks to months after starting immunosuppressive treatment. Both the nerve and the muscle may be involved. Axonal and demyelinating neuropathy have been reported. The more severe forms have been observed during Tac therapy, such as multifocal demyelinating neuropathy resembling chronic inflammatory demyelinating neuropathy (CIDP). Moreover, akinetic mutism and various aphasic and apractic syndromes may be seen in the setting of both Tac and CsA toxicity $[28,168]$. These usually improve with dosage reduction and careful monitoring of serum drug levels. Paradoxically, Tac showed neuroprotective properties in some experimental models of peripheral nerve injury [113]. The evidence for the existence of Tac-related peripheral neuropathy is still equivocal, and further studies are needed to firmly establish its pathophysiology and relevance. 
Muscle-related or neuromuscular adverse reactions have been reported with most of the immunosuppressive medications. As mentioned earlier, those include e.g. steroid-induced myopathy, myalgia and myopathy during CNIs use, myalgia observed in thymoglobulin-treated patients, tremor after mTOR inhibitors use, myasthenic syndrome reported for mycophenolate and neuromuscular block seen with azathioprine, musculoskeletal symptoms described as potentially related to cyclophosphamide and eculizumab.

\section{Behavioural disorders}

Corticosteroid therapy is one of cornerstones of immunosuppression protocols, used for maintenance therapy as well as for treatment of acute rejection. Direct neurologic complications include steroid-related psychosis, myopathy, and epidural lipomatosis. The incidence of acute side-effects is 3-4\% and the most common neurologic complications are behavioural disorders including confusion, mood disturbances, manic states and psychotic reactions [150]. Behavioural changes associated with steroid use range from minor mood disturbances to florid psychosis. Symptoms usually improve with dosage reduction or discontinuation of therapy, but occasionally, adjunct antidepressant and neuroleptic therapy needs to be considered. Repeated exposure to steroids does not routinely increase the risk of developing psychosis. Behavioural disorders, as already cited, were also linked to CNI, mTOR inhibitors and mycophenolate. Uncommon, rare or very rare cases of psychiatric/ behavioural changes were reported with AZA, cyclophosphamide, mycophenolate and eculizumab $[9,106]$.

\section{De novo CNS malignancies}

Organ transplant recipients have a three- to fourfold higher incidence of malignant disease compared with the general population [153], due to their reduced immunosurveillance and high incidence of infections involving oncogenic viruses. The incidence of post-transplant lymphoproliferative disorders has been estimated at less than $2 \%$ (with higher rates in the paediatric population) and $27 \%$ of cases involve the CNS and meninges $[46,95,155]$. In a recent report from database of 1421 adult patients who underwent renal transplantation from deceased or living donors in the period from 2007 to 2015 in the Slovak transplant centres, frequency of PTLD was found as $2.4 \%$ [240]. Patients undergoing heart-lung or liver-bowel transplantation are at the highest risk (5\%) for CNS malignancies, while the risk is lower with liver, cardiac and bone marrow allografts (1-2\%), and lowest with kidney transplantation $(<1 \%)$ [95]. The most frequent malignancies of the brain in renal transplant recipients are lymphomas and metastatic tumours which are, for the most part, de novo malignancies from immunosuppression. The most common malignant PTLD subtype is post-transplant diffuse large B-cell lymphoma (PT-DLBCL), followed by Burkitt lymphoma (PT-BL) and plasmablastic lymphoma (PT-PBL). PT-BL and PT-PBL are aggressive, but poorly studied malignant PTLD subtypes [133]. Many of the reported cases of CNS lymphomas are associated with prior EBV infections [151]: this condition is estimated to occur in 3\% of liver recipients [194] and in 1-2\% of kidney recipients [75]. The clinical manifestations vary and the final diagnosis is often based on cerebral biopsy [152]. Treatment options include reduction of immunosuppression, anti-CD20 monoclonal antibodies, and/or chemotherapy [118]. Localized disease may be successfully treated with radiotherapy or surgery [81].

Immunosuppressed allograft recipients have an increased incidence of cancer. An increased incidence of post-transplant lymphoproliferative disorder (PTLD) was also observed with use of antithymocyte immunoglobulin, OKT3, belatacept, CNIs $[9,10,50,106,121,138]$. Mycophenolate has not been linked to PTLD while for mTOR inhibitors the data have been inconclusive. As mTOR signalling pathways were shown to be activated in PTLD cases, protective effects were proposed for mTOR-inhibition in PTLD. However, recent studies reported slightly increased PTLD incidences during maintenance therapy with mTOR-I-based immunosuppression [138].

\section{CNS infection}

All immunosuppressive medications are associated with an increased rate of opportunistic infections. The presentation of CNS infection in transplant recipients can vary from that seen in normal population, as the anti-inflammatory effects of immunosuppressive therapy may obscure signs of meningeal inflammation associated with meningitis and changes in the level of consciousness may be subtle [72]. CNS infections in renal transplant recipients are associated with significant mortality and morbidity, which makes understanding of the need of special 
methods for detection and isolation of pathogens extremely important.

Opportunistic bacterial infections include pathogens such as: Legionella, Nocardia, Mycobacterium tuberculosis and Listeria monocytogenes. The involved fungal organisms are often: Cryptococcus neoformans, Aspergillus fumigatus, Candida, Pneumocystis carinii. Common viruses include Cytomegalovirus (CMV), Varicella-Zoster virus and Epstein-Barr virus (EBV), Herpes viruses 1 and 2 (HSV 1 and 2) and BK/ JC polyoma virus are less common. Acute meningitis, usually caused by L. monocytogenes, subacute and chronic meningitis caused by $C$. neoformans, focal brain infections caused by A. fumigatus, Toxoplasma gondii or Nocardia asteroids, and progressive dementia caused by Polyoma J virus were reported to be the most common CNS infections in kidney transplant recipients [160].

Acute and chronic allograft rejections require higher doses of immunosuppressive drugs and thus increase the risk of CNS infection. In reports published before 2000, CNS infections complicated the post-transplant course of $5 \%$ to $10 \%$ of allograft recipients with a high mortality rate of up to $75 \%$ [47] and in autopsy series, the incidence of CNS infections was even higher, reaching $10 \%$ to $16 \%[122,123]$. Recent reports indicate a declining incidence of CNS infections, which may be explained by declining immunosuppressive burden especially with polyclonal antibodies, doses of CNIs and steroids, and better diagnostics enabling earlier detection of the infection, and thus preventing its development into CNS infection. According to a review published in 2014, the incidence of the most common CNS infections stands approximately for: $0.1-0.2 \%$ for aspergillosis, cryptococci, fungal infection, and less than $0.05 \%$ for other infections including nocardiosis, JC virus PML, and moulds [230]. In a prospective, nation-wide population-based study in the Netherlands [211], carried out between 2006 and 2014, in data from 68,526 patient-years of follow-up of patients after solid organ transplantation, the annual incidence of bacterial meningitis was 7 -fold higher (95\% confidence interval [Cl]: 2.94-17.02, $p<0.001$ ) for renal transplant recipients as compared with the general population (9.56 [95\% Cl: 3.98-22.96] vs. 1.35 [95\% Cl: 1.28-1.43] per 100,000 patients per year). However, overall, only 6 cases were identified, with one case with the classic presentation of bacterial meningitis (fever, neck stiffness, and change in the mental sta- tus). Seizures were more common and were seen in $33 \%$ of patients. Pathogens responsible were Streptococcus pneumoniae and Listeria monocytogenes identified in 2 patients each, and Escherichia coli and Pseudomonas aeruginosa in the remaining patients [211].

Fungal CNS infections in solid organ transplantation seem more frequent. The overall cumulative incidence during the first year after transplantation is considered to be at the level of 3\% depending on the type of the organ transplanted [184]. In the decreasing order, the risk seen in transplantations stands for (incidence rate in brackets) - small bowel (11.6\%), lung (8.6\%), liver (4.7\%), heart (4.0\%), pancreas (3.4\%) and kidney (1.3\%). Candidiasis is the most common invasive fungal infection in SOT recipients and accounts for $50-60 \%$ infections, followed by aspergillosis accounting for $20-25 \%$ of fungal infections, then Cryptococcus species (6-7\%), the endemic fungi (5\%) and other species [148].

The CNS infection commonly results from dissemination of the systemic infection, where the lungs and gastrointestinal tract constitute common points of entry to the bloodstream. The paranasal sinuses are also critical routes of entry to the CNS, explaining, for instance, how fungal sinusitis may easily become fungal meningitis [139].

There is a correlation between time after transplantation and the organism that is most likely responsible for CNS infection [47]. In the acute perioperative period (first 30 days), the CNS infection is most likely related to nosocomial, pre-existing, or donor-related organisms. The risk of viral and fungal opportunistic infection is greatest one month post-transplantation, as immunosuppression becomes effective. Six months post-transplantation, infections reportedly result from reactivation of infections acquired earlier, opportunistic infections related to chronic immunosuppression, or common organisms found in immunocompetent patients. During the initial month, CNS infection is most often caused by common bacterial pathogens or opportunistic pathogens present in either the transplant environment (e.g. Aspergillus species), or host (e.g. Mycobacterium tuberculosis). At 1 to 6 months, there is increased susceptibility to CNS infection by the herpesviruses, especially CMV and Epstein-Barr virus (EBV), fungi, and atypical bacteria. Finally, after 6 months, reduction of immunosuppression is accompanied by decreased susceptibility to CNS infection [241]. 
One of the most frequent opportunistic bacteria infecting immunocompromised patients is Legionella pneumophila. It causes serious infection particularly in patients with impaired cellular immunity. However Legionella is not known as a frequent cause of CNS infections in solid organ transplant recipients [230].

Acute meningitis is usually caused by L. monocytogenes, subacute and chronic meningitis by $C$. neoformans, and focal brain infections by $A$. fumigatus. L. monocytogenes, contracted through ingestion of contaminated food, needs to be considered in transplant patients with symptoms and signs of meningoencephalitis. The classic pathogens like Haemophilus and Streptococcus pneumoniae are infrequently seen in the transplant population. Meningitis, with or without focal neurological signs, is the commonest form of CNS listeriosis; in addition, listeriosis may cause rhombencephalitis, abscesses, and even myelitis [58].

Mycobacterium is rarely implicated as a CNS pathogen in transplant patients [34]. Immunosuppression may facilitate the progression of a latent, quiescent mycobacterial infection. Pulmonary tuberculosis and atypical mycobacterial CNS infections share similar treatment algorithms. CNS infections may be exceedingly difficult to diagnose, requiring multiple lumbar punctures and polymerase chain reaction studies. Three main presentations of $M$. tuberculosis in the CNS have been described: cerebral tuberculoma, meningitis and myelopathy [192].

Nocardia asteroides is another organism that is rarely recognised in immunocompetent persons, but in transplant patients it may cause subacute or chronic meningitis as well as cerebritis. Nocardia infections were reported in $1 \%$ to $6 \%$ of solid organ transplant recipients and in fewer than $5 \%$ of renal transplant recipients [41,49]. In nocardiosis, pulmonary infection usually precedes CNS involvement [47]. Guillain-Barré syndrome may also develop, associated in some cases with CMV or Campylobacter jejuni infection [79].

Cryptococcal meningitis is the most common subacute meningitis seen in renal transplant recipients, especially in patients who are exposed to birds, and is universally fatal without treatment. Like all other fungi, cryptococci enter the body through the respiratory tract but CNS is the primary target [92,232]. Symptoms may show and disappear over time and include e.g. headaches, fever, lethargy, abnormal mental status, and coma. Elevated CSF pressure without evidence of obstructive hydrocephalus, believed to result from basilar meningitis and impaired reabsorption of CSF across arachnoid villi, was reported as an important complication of cryptococcal meningitis [92]. In a retrospective analysis of solid organ transplant recipients with cryptococcosis, it was found that $30 \%$ of them had changes in computed tomography (CT) or MR. Abnormal neuroimaging findings corresponding with the cryptococcal lesions included leptomeningeal lesions in $50 \%$ (8/16), parenchymal lesions in $37.5 \%(6 / 16)$, and hydrocephalus in $12.5 \%(2 / 16)$ [188].

It needs to be mentioned that some immunosuppressive agents (cyclosporine, tacrolimus, mTOR inhibitors) have in vitro activity against fungi, including C. neoformans [92], and its clinical relevance was confirmed by a multivariable analysis of data from a large study showing that the receipt of a CNI was independently associated with a lower mortality (adjusted HR, 0.21; $p=0.008$ ) [187].

In invasive aspergillosis, CNS involvement frequently presents with altered mental status, seizures, focal neurologic deficit, with brain abscess most common location being the fronto-parietal region of the cerebral hemispheres, though the cerebellum and brainstem may also be involved. As Aspergillus is an angioinvasive pathogen, cerebral infarcts or haemorrhagic lesions can be found [201]. In a recent summary of a series of cases it was reported that mortality among CNS aspergillosis patients remains high, and suggested that the infection may be more common among patients with previous brain pathology [104].

Herpes virus infections are extremely common in renal transplant recipients but meningoencephalitis is a rare and potentially life-threatening complication mostly caused by HSV-1. Varicella-zoster virus, apart from varicella (chickenpox) and herpes zoster (shingles), may lead to CNS complications such as post-varicella cerebellitis, meningoencephalitis (including the Ramsay Hunt syndrome), vasculopathy, and acute aseptic meningitis. Comparing to normal population, post-transplant patients with zoster are more likely to develop post-herpetic neuralgia [241].

Cytomegalovirus (CMV) is an uncommon cause of encephalitis or Guillain-Barré syndrome in solid organ transplant [237]. Reactivated latent JC virus is found in more than $90 \%$ of patients with PML [125]. PML symptoms may include mental status changes, visual field deficits, focal neurologic deficit, while in neuroimaging single or multiple non-enhancing 
white matter lesions in CT or MRI lesions most often in the parieto-occipital region are seen [241].

In post-transplant patients, EBV infection can be a primary infection or reactivation of latent infection. It can be associated with meningoencephalitis and an abnormal proliferation of lymphoid cells, causing aseptic meningitis, seizures, encephalitis, or PTLD [230,241]. Twenty-eight percent of patients with PTLD have CNS involvement, and EBV-associated PTLD may be characterized by a mental status change, hemiparesis, or other focal neurologic deficit. In neuroimaging, the focal lesion with variable enhancement can be seen and may have associated haemorrhage or leptomeningeal spread [241].

Immunocompromised kidney transplant recipients may also develop other opportunistic infections, like parasite infections, although rarely affecting the nervous system [241]. Toxoplasmosis is an example with CNS involvement occurring very rarely. In a long, multicentre, matched case-control study in Spain, toxoplasmosis developed in $0.14 \%$ of solid organ transplant recipients and toxoplasma-related brain abscesses or meningitis developed in approx. $25 \%$ of those very few cases [69].

\section{Future considerations}

Organ transplantation is one of the most dynamic fields in medicine and continuously improving outcomes have been achieved in the field of renal transplantation. A significant reduction in acute rejection has been attained at many renal transplant centres using contemporary immunosuppressive therapy. Long-term use of these drugs has been associated with the development of chronic allograft nephropathy and other adverse events. The common neurologic complications such as stroke, encephalopathy, behavioural disorders, neuromuscular complications, CNS de novo malignancies, and opportunistic infections still persist. Functional data in healthy human subjects are required to clarify the genuine CNS effects of immunosuppressants in order to be able to differentiate between these drug effects and the CNS effects of transplantation. As more patients are experiencing prolonged survival, the number of patients at risk for chronic complications is increasing, therefore personalizing the immunosuppression therapy to the individual needs of the patient may be favourable. The perfect immunosuppressive regimen would limit or eliminate calcineurin inhibitors neurotoxicity while providing enhanced allograft outcomes. Potential improvements to the calcineurin inhibitor class include a prolonged release tacrolimus formulation. On the other hand, PTLD risk has challenged introduction of belatacept, otherwise a promising novel solution. Moreover, new immunosuppressive agents which eliminate these issues are desirable. As the field of organ transplantation continues to evolve, research should be conducted to create suitable drugs that sustain immunotolerance in transplantation medicine, eliminating the previously mentioned adverse effects.

\section{Disclosure}

Authors report no conflict of interest.

\section{References}

1. Abedini S, Holme I, Fellström B, Jardine A, Cole E, Maes B, Holdaas H; ALERT Study Group. Cerebrovascular events in renal transplant recipients. Transplantation 2009; 87: 112-117.

2. Abelaira HM, Réus GZ, Neotti MV, Quevedo J. The role of mTOR in depression and antidepressant responses. Life Sci 2014; 101: 10-14.

3. Abramowicz D, De Pauw L, Le Moine A, Sermon F, Surquin M, Doutrelepont JM, Ickx B, Depierreux M, Vanherweghem JL, Kinnaert P, Goldman M, Vereerstraeten P. Prevention of OKT3 nephrotoxicity after kidney transplantation. Kidney Int Suppl 1996; 53: S39-43.

4. Adams HP Jr, Dawson G, Coffman TJ, Corry RJ. Stroke in renal transplant recipients. Arch Neurol 1986; 43: 113-115.

5. Ahmed S, Ahmed E, Naqvi R, Qureshi S. Evaluation of contributing factors of post transplant erythrocytosis in renal transplant patients. J Pak Med Assoc 2012; 62: 1326-1329.

6. Ahsan N, Johnson C, Gonwa T, Halloran P, Stegall M, Hardy M, Metzger R, Shield C 3rd, Rocher L, Scandling J, Sorensen J, Mulloy L, Light J, Corwin C, Danovitch G, Wachs M, VanVeldhuisen P, Salm K, Tolzman D, Fitzsimmons WE. Randomized trial of tacrolimus plus mycophenolate mofetil or azathioprine versus cyclosporine oral solution (modified) plus mycophenolate mofetil after cadaveric kidney transplantation: results at 2 years. Transplantation 2001; 72: 245-250.

7. Aksamit AJ, Ellingson RJ, Sharbrough FW, Westmoreland BF, Pfeiffer RF, Steg RE, de Groen PC. Epileptiform electroencephalographic abnormalities in liver transplant recipients. Ann Neurol 1991; 30: 37-41.

8. Albring A, Wendt L, Harz N, Engler H, Wilde B, Witzke O, Schedlowski M. Short-term treatment with the calcineurin inhibitor cyclosporine A decreases HPA axis activity and plasma noradrenaline levels in healthy male volunteers. Pharmacol Biochem Behav 2014; 126: 73-76.

9. Alemtuzumab, Summary of Product Characteristics, 2011, http://www.ema.europa.eu/docs/en_GB/document_library/ EPAR_-_Product_Information/human/000353/ WC500025270. pdf. 
10. Al-Mansour Z, Nelson BP, Evens AM. Post-transplant lymphoproliferative disease (PTLD): risk factors, diagnosis, and current treatment strategies. Curr Hematol Malig Rep 2013; 8: 173-183.

11. Anghel D, Tanasescu R, Campeanu A, Lupescu I, Podda G, Bajenaru O. Neurotoxicity of immunosuppressive therapies in organ transplantation. Maedica (Buchar) 2013; 8: 170-175.

12. Anil Kumar MS, Irfan Saeed M, Ranganna K, Malat G, SustentoReodica N, Kumar AM, Meyers WC. Comparison of four different immunosuppression protocols without long-term steroid therapy in kidney recipients monitored by surveillance biopsy: five-year outcomes. Transpl Immunol 2008; 20: 32-42.

13. Arnold R, Pussell BA, Pianta TJ, Lin CS, Kiernan MC, Krishnan AV. Association between calcineurin inhibitor treatment and peripheral nerve dysfunction in renal transplant recipients. Am J Transplant 2013; 13: 2426-2432.

14. Atamaz F, Hepgüler S, Karasu Z, Kilic M. Meralgia paresthetica after liver transplantation: a case report. Transplant Proc 2005; 37: 4424-4425.

15. Azathioprine Summary of Product Characteristics 2016; http:// www.medicines.org.uk/emc/medicine/29130/SPC/Azathioprine+50+mg+Tablets.

16. Bakshi R, Bates VE, Mechtler LL, Kinkel PR, Kinkel WR. Occipital lobe seizures as the major clinical manifestation of reversible posterior leukoencephalopathy syndrome: magnetic resonance imaging findings. Epilepsia 1998; 39: 295-299.

17. Barnett AN, Asgari E, Chowdhury P, Sacks SH, Dorling A, Mamode N. The use of eculizumab in renal transplantation. Clin Transplant 2013; 27: E216-29.

18. Barnett AN, Hadjianastassiou VG, Mamode N. Rituximab in renal transplantation. Transpl Int 2013; 26: 563-575.

19. Bart H, Malik SA International Report About Kidney Diseases in 4 European Countries; www.nvn.nl 20153.

20. Basiliximab, Summary of Product Characteristics 2008, http:// www.ema.europa.eu/docs/en_GB/document_library/EPAR_Product_Information/human/000207/ WC500053543.pdf.

21. Basso G, Cristelli M, Bichuetti D, Franco M, Baptista A, SandesFreitas T, Gusuma L, Gomes P, Tedesco H, Medina-Pestana J. Major Neurological Complications Following Renal Transplantation [abstract]. Am J Transplant 2013; 13 Suppl 5.

22. Becker H, Reichert JM. MuromonabCD3 (Orthoclone OKT®3). In: Handbook of Therapeutic Antibodies. Dübel S, Reichert JM (eds.). WileyVCH Verlag GmbH \& Co. KGaA, Weinheim, Germany 2014.

23. Belatacept Summary of Product Characteristics 2014; https:// ec.europa.eu/health/documents/community-register/2014/ 20141216130471/anx_130471_en.pdf.

24. Benchstein WO. Neurotoxicity of calcineurin inhibitors: impact and clinical management. Transplant Int 2000; 13: 313-326.

25. Berger JR, Neltner J, Smith C, Cambi F. Posterior reversible encephalopathy syndrome masquerading as progressive multifocal leukoencephalopathy in rituximab treated neuromyelitis optica. Mult Scler Relat Disord 2014; 3: 728-731.

26. Besenski N, Rumboldt Z, Emovon O, Nicholas J, Kini S, Milutinovic J, Budisavljevic MN. Brain MR imaging abnormalities in kidney transplant recipients. Am J Neuroradiol 2005; 26: 22822289.
27. Bianco F, Fattapposta F, Locuratolo N, Pierallini A, Rossi M, Ruberto F, Bozzao L. Reversible diffusion MRI abnormalities and transient mutism after liver transplantation. Neurology 2004; 62: 981-983.

28. Bird GL, Meadows J, Goka J, Polson R, Williams R. Cyclosporinassociated akinetic mutism and extrapyramidal syndrome after liver transplantation. J Neurol Neurosurg Psych 1990; 53 : 1068-1071.

29. Bodziak KA, Hricik DE. New-onset diabetes mellitus after solid organ transplantation. Transpl Int 2009; 22: 519-530.

30. Bolton CF, Young GB, Zochodne DW. The neurological complications of sepsis. Ann Neurol 1993; 33: 94-100.

31. Bouguen G, Evans E, Sandborn WJ. Azathioprine-induced neuropsychiatric disorders. J Crohns Colitis 2014; 8: 180.

32. Bowyer SL, LaMothe MP, Hollister JR. Steroid myopathy: incidence and detection in a population with asthma. J Allergy Clin Immunol 1985; 76: 234-242

33. Breil M, Chariot P. Muscle disorders associated with cyclosporine treatment. Muscle Nerve 1999; 22: 1631-1636.

34. Bronster DJ, Emre S, Boccagni P, Sheiner PA, Schwartz ME, Miller CM. Central nervous system complications in liver transplant recipients - incidence, timing and long-term follow-up. Clin Transplantation 2000; 14: 1-7.

35. Bürker BS, Gullestad L, Gude E, Relbo Authen A, Grov I, Hol PK, Andreassen AK, Arora S, Dew MA, Fiane AE, Haraldsen IR, Malt UF, Andersson S. Cognitive function after heart transplantation: Comparing everolimus-based and calcineurin inhibitor-based regimens. Clin Transplant 2017; 31: e12927.

36. Campellone JV, Lacomis D, Kramer DJ, Van Cott AC, Giuliani MJ. Acute myopathy after liver transplantation. Neurology 1998; 50: 46-53.

37. Campellone JV, Lacomis D. Neuromuscular disorders. In: Wijdicks EFM (Hrsg). Neurologic complications in organ transplant recipients. Butterworth Heinemann, Boston 1999; 169-192.

38. Cejka D, Hayer S, Niederreiter B, Sieghart W, Fuereder T, Zwerina J, Schett G. Mammalian target of rapamycin signaling is crucial for joint destruction in experimental arthritis and is activated in osteoclasts from patients with rheumatoid arthritis. Arthritis Rheum 2010; 62: 2294-2302.

39. Chadban SJ, Barraclough KA, Campbell SB, Clark CJ, Coates PT, Cohney SJ, Cross NB, Eris JM, Goodman D, Henderson L, Howell MR, Isbel NM, Kanellis J, Kotwal SS, Manley P, Masterson R, Mulley W, Murali K, O'Connell P, Pilmore H, Pussell B, Rogers N, Russ GR, Walker RG, Webster AC, Wiggins KJ, Wong G, Wyburn KR. The Kidney Health Australia-Caring for Australasians with Renal Impairment (KHA-CARI) Guidelines: KHA-CARI adaptation of the KDIGO Clinical Practice Guideline for the Care of Kidney Transplant Recipients. Nephrology 2012; 17: 204-214.

40. Chang SH, Lim CS, Low TS, Chon HT, Tan SY. Cyclosporine associated encephalopathy: a case report and literature review. Transplant Proc 2001; 8: 3700-3701.

41. Chapman SW, Wilson JP. Nocardiosis in transplant recipients. Semin Respir Infect 1990; 5: 74.

42. Chen SR, Hu YM, Chen H, Pan HL. Calcineurin inhibitor induces pain hypersensitivity by potentiating pre- and postsynaptic NMDA receptor activity in spinal cords. J Physiol 2014; 592: 215-227. 
43. Chtioui H, Zimmermann A, Dufour JF. Unusual evolution of posterior reversible encephalopathy syndrome (PRES) one year after liver transplantation. Liver Transpl 2005; 11: 588-590.

44. Ciriaco M, Ventrice P, Russo G, Scicchitano M, Mazzitello G, Scicchitano F, Russo E. Corticosteroid-related central nervous system side effects. J Pharmacol Pharmacother 2013; 4 Suppl 1: S94-98.

45. Collini A, De Bartolomeis C, Barni R, Ruggieri G, Bernini M, Carmellini M. Calcineurin-inhibitor induced pain syndrome after organ transplantation. Kidney Int 2006; 70: 1367-1370.

46. Collins MH, Montone KT, Leahey AM, Hodinka RL, Salhany KE, Belchis DA, Tomaszewski JE. Autopsy pathology of pediatric posttransplant lymphoproliferative disorder. Pediatrics 2001; 107: E89.

47. Conti DJ, Rubin RH. Infection of the central nervous system in organ transplant recipients. Neurol Clin 1988; 6: 241-260.

48. Coplin WM, Cochran MS, Levine SR, Crawford SW. Stroke after bone marrow transplantation: frequency, aetiology and outcome. Brain 2001; 124: 1043-1051.

49. Coussement J, Lebeaux D, van Delden C, Guillot H, Freund R, Marbus S, Melica G, Van Wijngaerden E, Douvry B, Van Laecke S, Vuotto F, Tricot L, Fernández-Ruiz M, Dantal J, Hirzel C, Jais JP, Rodriguez-Nava V, Lortholary O, Jacobs F; European Study Group for Nocardia in Solid Organ Transplantation. Nocardia Infection in Solid Organ Transplant Recipients: A Multicenter European Case-control Study. Clin Infect Dis 2016; 63: 338-345.

50. Curtis RE, Travis LB, Rowlings PA, Socié G, Kingma DW, Banks PM, Jaffe ES, Sale GE, Horowitz MM, Witherspoon RP, Shriner DA, Weisdorf DJ, Kolb HJ, Sullivan KM, Sobocinski KA, Gale RP, Hoover RN, Fraumeni JF Jr, Deeg HJ. Risk of lymphoproliferative disorders after bone marrow transplantation: a multi-institutional study. Blood 1999; 94: 2208-2216.

51. Cyclophosphamide Summary of Product Characteristics 2014; https://www.medicines.org.uk/emc/medicine/29593 (Acces: 21.05.2017)

52. Dawson FM. Immunosoppressants, immunophilins and the nervous system. Ann Neurol 1996; 40: 559-560.

53. de Groen PC, Aksamit AJ, Rakela J, Forbes GS, Krom RA. Central nervous system toxicity after liver transplantation. Role of cyclosporine and cholesterol. N Engl J Med 1987; 317: 861-866.

54. de Paula MI, Medina Pestana JO, Nicolau Ferreira A, Pontello Cristelli M, Fabiano Franco M, Aguiar WF, Tedesco-Silva H, Rosso Felipe C. Long-Term Follow-Up of De Novo Use of mTOR and Calcineurin Inhibitors After Kidney Transplantation. Ther Drug Monit 2016; 38: 22-31.

55. Decramer M, Stas KJ. Corticosteroid-induced myopathy involving respiratory muscles in patients with chronic obstructive pulmonary disease or asthma. Am Rev Respir Dis 1992; 146: 800-802.

56. Dhillon SS, Sarac E. Lumbosacral plexopathy after dual kidney transplantation. Am J Kidney Dis 2000; 36: 1045-1048.

57. Dietrich J, Rao K, Pastorino S, Kesari S. Corticosteroids in brain cancer patients: benefits and pitfalls. Expert Rev Clin Pharmacol 2011; 4: 233-242.

58. Doganay M. Listeriosis: clinical presentation. FEMS Immunol Med Microbiol 2003; 35: 173-175.
59. Draper HM. Depressive disorder associated with mycophenolate mofetil. Pharmacotherapy 2008; 28: 136-139.

60. Eberlein WR, Bongiovanni AM, Rodriguez CS. Diagnosis and treatment: the complications of steroid treatment. Pediatrics 1967; 40: 279-282.

61. Eckhard M, Schindler RA, Renner FC, Schief W, Padberg W, Weimer R, Bretzel RG, Brendel MD. New-onset diabetes mellitus after renal transplantation. Transplant Proc 2009; 41: 25442545.

62. Eculizumab Summary of Product Characteristics 2012ł http:// www.ema.europa.eu/docs/en GB/document library/EPAR Product_Information/human/000791/WC500054208.pdf.

63. Eidelman BH, Abu-Elmagd K, Wilson J, Fung JJ, Alessiani M, Jain A, Takaya S, Todo SN, Tzakis A, Van Thiel D, Shannon W, Starzl TE. Neurologic complications of FK 506. Transplant Proc 1991; 23: 3175-3178.

64. Ekberg H, Tedesco-Silva H, Demirbas A, Vítko S, Nashan B, Gürkan A, Margreiter R, Hugo C, Grinyó JM, Frei U, Vanrenterghem Y, Daloze P, Halloran PF, ELITE-Symphony Study. Reduced exposure to calcineurin inhibitors in renal transplantation. N Engl J Med 2007; 357: 2562-2575.

65. Ellul-Micallef R, Fenech FF. Effect of intravenous prednisolone in asthmatics with diminished adrenergic responsiveness. Lancet 1975; 2: 1269-1271.

66. Eugui EM, Almquist SJ, Muller CD, Allison AC. Lymphocyte-selective cytostatic and immunosuppressive effects of mycophenolic acid in vitro: role of deoxyguanosine nucleotide depletion. Scand J Immunol 1991; 33: 161-173.

67. Fallon B, Rayhill S. Ranal Transplantation: Surgical Procedure and Complications. In: Dreger D (ed.). Hospital Physician Urology Board Review Manual. Turner White Communications, Inc., Wayne 2004; 2-12.

68. FDA Department of Health and Human Services Belatacept BLA Approval Letter 2011; https://www.accessdata.fda.gov/ drugsatfda docs/appletter/2011/125288s000ltr.pdf.

69. Fernàndez-Sabé N, Cervera C, Fariñas MC, Bodro M, Muñoz P, Gurguí M, Torre-Cisneros J, Martín-Dávila P, Noblejas A, Len O, García-Reyne A, Del Pozo JL, Carratalà J. Risk factors, clinical features, and outcomes of toxoplasmosis in solid-organ transplant recipients: a matched case-control study. Clin Infect Dis 2012; 54: 355-361.

70. Fessler RG, Johnson DL, Brown FD, Erickson RK, Reid SA, Kranzler L. Epidural lipomatosis in steroid-treated patients. Spine 1992; 17: 183-188.

71. Findlay MD, Thomson PC, Maclsaac R, Jardine AG, Patel RK, Stevens KK, Rutherford E, Clancy M, Geddes CC, Dawson J, Mark PB. Risk factors and outcome of stroke in renal transplant recipients. Clin Transplant 2016; 30: 918-924.

72. Fishman JA, Rubin RH. Infection in organ-transplant recipients. N Engl J Med 1998; 338: 1741-1751.

73. Flynn JT, Bunchman TE, Sherbotie JR. Indications, results, and complications of tacrolimus conversion in pediatric renal transplantation. Pediatr Transplant 2001; 5: 439-446.

74. Furukawa M, Terae S, Chu BC, Kaneko K, Kamada H, Miyasaka K. MRI in seven cases of Tacrolimus FK 506 encephalopathy: utility of flair and diffusion-weighted imaging. Neuroradiology 2001; 43: 615-621. 
75. Gill D, Juffs HG, Herzig KA, Brown AM, Hawley CM, Cobcroft RG, Petrie JJ, Marlton P, Kennedy G, Thomson DB, Campbell SB, Nicol DL, Norris D, Johnson DW. Durable and high rates of remission following chemotherapy in posttransplantation lymphoproliferative disorders after renal transplantation. Transpl Proc 2003; 35: 256-257.

76. Giunzioni I, Tavori H. New developments in atherosclerosis: clinical potential of PCSK9 inhibition. Vasc Health Risk Manag 2015; 11: 493-501.

77. Goldstein LS, Haug MT 3rd, Perl J 2nd, Perl MK, Maurer JR, Arroliga AC, Mehta AC, Kirby T, Higgins B, Stillwell PC. Central nervous system complications after lung transplantation. J Heart Lung Transplant 1998; 17: 185-191.

78. Griffiths PD, Clark DA, Emery VC. Betaherpesviruses in trans plant recipients. J Antimicrob Chemother 2000; 45 Suppl T3: 29-34.

79. Grygorczuk S, Zajkowska J, Kondrusik M, Pancewicz S, Hermanowska-Szpakowicz T. Guillain-Barré syndrome and its association with infectious factors. Neurol Neurochir Pol 2005: 39: 230-236.

80. Guertin DA, Sabatini DM. The pharmacology of mTOR inhibition. Sci Signal 2009; 2: pe24.

81. Habibeh O, Elsayad K, Kriz J, Haverkamp U, Eich HT. Post-transplant lymphoproliferative disorder in the pelvis successfully treated with consolidative radiotherapy. Strahlenther Onkol 2017; 193: 80-85

82. Halloran P, Kung L, Noujaim J. Calcineurin and the biological effect of cyclosporine and tacrolimus. Transplant Proc 1998; 30: 2167-2170.

83. Halloran PF. Immunosuppressive drugs for kidney transplantation. N Engl I Med 2004; 351: 2715-2729.

84. Hardinger KL, Brennan DC. Novel immunosuppressive agents in kidney transplantation. World J Transplant 2013; 3: 68-77.

85. Heitman J, Movva NR, Hall MN. Targets for cell cycle arrest by the immunosuppressant rapamycin in yeast. Science 1991; 253: 905-909.

86. Hellemans R, Bosmans JL, Abramowicz D. Induction Therapy for Kidney Transplant Recipients: Do We Still Need Anti-IL2 Receptor Monoclonal Antibodies? Am J Transplant 2017; 17: 22-27.

87. Hill P, Cross NB, Barnett AN, Palmer SC, Webster AC. Polyclonal and monoclonal antibodies for induction therapy in kidney transplant recipients. Cochrane Database Syst Rev 2017; 1 CD004759.

88. Hinchey J, Chaves C, Appignani B, Breen J, Pao L, Wang A, Pessin MS, Lamy C, Mas JL, Caplan LR. A reversible posterior leukoencephalopathy syndrome. N Engl J Med 1996; 334: 494-500.

89. Holdaas H, Potena L, Saliba F. mTOR inhibitors and dyslipidemia in transplant recipients: a cause for concern? Transplant Rev (Orlando) 2015; 29: 93-102.

90. Hopkins S, Jolles S. Drug-induced aseptic meningitis. Expert Opin Drug Saf 2005; 4: 285-297.

91. Huberlant V, Cosnard G, Hantson PE. Brain death in a septic patient: possible relationship with posterior reversible encephalopathy syndrome? Anaesth Intensive Care 2009; 37: 1017 1020.
92. Husain S, Wagener MM, Singh N. Cryptococcus neoformans infection in organ transplant recipients: variables influencing clinical characteristics and outcome. Emerg Infect Dis 2001; 7: 375-381.

93. Illsinger S, Janzen N, Lücke T, Bednarczyk J, Schmidt KH, Hoy L, Sander J, Das AM. Cyclosporine A: impact on mitochondrial function in endothelial cells. Clin Transplant 2011; 25: 584-593.

94. Inoha S, Inamura T, Nakamizon A, Ikezaki K, Amono T, Fukui M. Magnetic resonance imaging in cases with encephalopathy secondary to immunosuppressive agents. J Clin Neurosci 2002; 9: 305-307.

95. Jaffe ES, Harris NL, Stein H. In: Pathology and Genetics of Tumor and Haematopoietic Tissues. Jaffe ES (ed.). World Health Organization Classification of Tumors. IARC Press: Oxford University Press, Lyon 2001; 264-270.

96. Johnson CK, Leca N. Eculizumab use in kidney transplantation. Curr Opin Organ Transplant 2015; 20: 643-651.

97. Kahan BD. Role of cyclosporine: present and future. Transplant Proc 1994; 26: 3082-3087.

98. Kalluri HV, Hardinger KL. Current state of renal transplant immunosuppression: Present and future. World J Transplant 2012; 2: 51-68.

99. Kapur S, Jones WG 2nd, Barber AE, Minei JP, Fahey TJ 3rd, Shires GT 3rd, Shires GT. Effect of cyclosporine on adrenocortical response to injury and infection. J Surg Res 1992; 53: 357-361.

100. Kazory A, Ducloux D. Acquired hypercoagulable state in renal transplant recipients. Thromb Haemost 2004; 91: 646-654.

101. Kidney Disease: Improving Global Outcomes (KDIGO) Transplant Work Group. KDIGO clinical practice guideline for the care of kidney transplant recipients. Am J Transplant 2009; 9 Suppl 3: S1-155.

102. Klawitter J, Gottschalk S, Hainz C, Leibfritz D, Christians U, Serkova NJ. Immunosuppressant neurotoxicity in rat brain models: oxidative stress and cellular metabolism. Chem Res Toxicol 2010; 23: 608-619.

103. Klawitter J, Nashan B, Christians U. Everolimus and sirolimus in transplantation-related but different. Expert Opin Drug Saf 2015; 14: 1055-1070.

104. Kourkoumpetis TK, Desalermos A, Muhammed M, Mylonakis E. Central nervous system aspergillosis: a series of 14 cases from a general hospital and review of 123 cases from the literature. Medicine (Baltimore) 2012; 91: 328-336.

105. Krishnan AV, Lin CS, Kiernan MC. Activity-dependent excitability changes suggest $\mathrm{Na}+/ \mathrm{K}+$ pump dysfunction in diabetic neuropathy. Brain 2008; 131: 1209-1216.

106. Kumar A, Shrestha BM. Evolution of Immunosuppressive Agents in Renal Transplantation: An Updated Review. Int J Stem Cell Res Transplant 2016; 04(3): 158-172.

107. Lacomis D, Petrella JT, Giuliani MJ. Causes of neuromuscular weakness in the intensive care unit: a study of ninety-two patients. Muscle Nerve 1998; 21: 610-617

108. Lai S, Mecarelli O, Pulitano P, Romanello R, Davi L, Zarabla A, Mariotti A, Carta M, Tasso G, Poli L, Mitterhofer AP, Testorio M, Frassetti N, Aceto P, Galani A, Lai C. Neurological, psychological, and cognitive disorders in patients with chronic kidney disease on conservative and replacement therapy. Medicine (Baltimore) 2016; 95: e5191. 
109. Lake KD, Canafax DM. Important interactions of drugs with immunosuppressive agents used in transplant recipients. J Antimicrob Chemother 1995; 36: 11-22.

110. Lamy C, Oppenheim C, Meder JF, Mas JL. Neuroimaging in pos terior reversible encephalopathy syndrome. J Neuroimaging 2004; 14: 89-96.

111. Lang UE, Heger J, Willbring M, Domula M, Matschke K, Tugtekin SM. Immunosuppression using the mammalian target of rapamycin (mTOR) inhibitor everolimus: pilot study shows significant cognitive and affective improvement. Transplant Proc 2009; 41: 4285-4288.

112. Larsen CP, Pearson TC, Adams AB, Tso P, Shirasugi N, Strobert E, Anderson D, Cowan S, Price K, Naemura J, Emswiler J, Greene J, Turk LA, Bajorath J, Townsend R, Hagerty D, Linsley PS, Peach RJ. Rational development of LEA29Y (belatacept), a high-affinity variant of CTLA4-Ig with potent immunosuppressive properties. Am J Transplant 2005; 5: 443-453.

113. Lee M, Doolabh VB, Mackinnon SE, Jost S. FK506 promotes functional recovery in crushed rat sciatic nerve. Muscle Nerve 2000; 23: 633-640

114. Legendre C, Sberro-Soussan R, Zuber J, Rabant M, Loupy A, Timsit MO, Anglicheau D. Eculizumab in renal transplantation. Transplant Rev (Orlando) 2013; 27: 90-92.

115. Leist M, Nicotera P. Apoptosis, excitotoxicity, and neuropathology. Exp Cell Res 1998; 239: 183-201.

116. Liu J, Liu D, Li J, Zhu L, Zhang C, Lei K, Xu Q, You R. Efficacy and Safety of Everolimus for Maintenance Immunosuppression of Kidney Transplantation: A Meta-Analysis of Randomized Controlled Trials. PLoS One 2017; 12: e0170246.

117. Liu LS, Li J, Chen XT, Zhang HX, Fu Q, Wang HY, Xiong YY, Liu S, Liu XM, Li J, Huang M, Wang CX. Comparison of tacrolimus and cyclosporin A in CYP3A5 expressing Chinese de novo kidney transplant recipients: a 2-year prospective study. Int J Clin Pract Suppl 2015; 183: 43-52.

118. Llaurador G, McLaughlin L, Wistinghausen B. Management of post-transplant lymphoproliferative disorders. Curr Opin Pediatr 2017; 29: 34-40.

119. Luzzio CC, Waclawik AJ, Gallagher CL, Knechtle SJ. Iliac artery pseudoaneurysm following renal transplantation presenting as lumbosacral plexopathy. Transplantation 1999; 67: 1077-1078.

120. Margreiter R. Efficacy and safety of tacrolimus compared with ciclosporin microemulsion in renal transplantation: a randomised multicentre study. Lancet 2002; 359: 741-766.

121. Martin ST, Powell JT, Patel M, Tsapepas D. Risk of posttransplant lymphoproliferative disorder associated with use of belatacept. Am J Health Syst Pharm 2013; 70: 1977-1983.

122. Martinez AJ. The neurology and neuropathology of hepatobiliary and pancreatic transplantation. In: Handbook of Clinical Neurology. Goetz CG, Aminoff MJ (eds.). Systemic diseases, Part II. Elsevier, Amsterdam 1998; 249-266.

123. Martinez AJ. The neuropathology of organ transplantation: comparison and contrast in 500 patients. Pathol Res Pract 1998; 194: 473-486.

124. McAlister VC, Peltekian KM, Malatjalian DA, Colohan S, MaCDonald S, Bitter-Suermann H, MacDonald AS. Orthotopic liver transplantation using low dose tacrolimus and sirolimus. Liver Transpl 2001; 7: 701-708.
125. McGuire D, Barhite S, Hollander H, Miles M. JC virus DNA in cerebrospinal fluid of human immunodeficiency virus-infected patients: Predictive value for progressive multifocal leukoencephalopathy. Ann Neurol 1995; 37: 395-399. Published erratum in Ann Neurol 37: 687, 1995.

126. McTaggart S. The CARI guidelines. Calcineurin inhibitors in paediatric renal transplantation. Nephrology (Carlton) 2007; 12 Suppl 1: S106-110.

127. Mele TS, Halloran PF. The use of mycophenolate mofetil in transplant recipients. Immunopharmacology 2000; 47: 215-245.

128. Meregalli C. An Overview of Bortezomib-Induced Neurotoxicity. Toxics 2015; 3: 294-303.

129. Michael M, Minard CG, Kale AS, Brewer ED. Outcomes of twodrug maintenance immunosuppression for pediatric renal transplantation: 10-yr follow-up in a single center. Pediatr Transplant 2016; 20: 49-58.

130. Mignat C. Clinically significant drug interactions with new immunosuppressive agents. Drug Safety 1997; 16: 267-278.

131. Moes DJ, Guchelaar HJ, de Fijter JW. Sirolimus and everolimus in kidney transplantation. Drug Discov Today 2015; 20: 12431249 .

132. Mogyoros I, Bostock H, Burke D. Mechanisms of paresthesias arising from healthy axons. Muscle Nerve 2000; 23: 310-320.

133. Morscio J, Tousseyn T. Recent insights in the pathogenesis of post-transplantation lymphoproliferative disorders. World J Transplant 2016; 6: 505-516.

134. Moskowitz A, Nolan C, Lis E, Castro-Malaspina H, Perales MA. Posterior reversible encephalopathy syndrome due to sirolimus. Bone Marrow Transplant 2007; 39: 653-654.

135. Mourad G, Garrigue V, Squifflet JP, Besse T, Berthoux F, Alamartine E, Durand D, Rostaing L, Lang P, Baron C, Glotz D, Antoine C, Vialtel P, Romanet T, Lebranchu Y, Al Najjar A, Hiesse C, Potaux L, Merville P, Touraine JL, Lefrancois N, Kessler M, Renoult E, Pouteil-Noble C, Cahen R, Legendre C, Bedrossian J, Le Pogamp P, Rivalan J, Olmer M, Purgus R, Mignon F, Viron B, Charpentier B. Induction versus noninduction in renal transplant recipients with tacrolimus-based immunosuppression. Transplantation 2001; 72: 1050-1055.

136. Mueller AR, Platz KP, Bechstein WO, Schattenfroh N, Stoltenburg-Didinger G, Blumhardt G, Christe W, Neuhaus P. Neurotoxicity after orthotopic liver transplantation. A comparison between cyclosporine and FK506. Transplantation 1994; 58 : 155-170.

137. Mycophenolate mofetil Summary of Product Characteristics 2006; http://www.ema.europa.eu/docs/en_GB/document_library/EPAR_-_Product_Information/human/000082/ WC500021864.pdf.

138. Mynarek M, Schober T, Behrends U, Maecker-Kolhoff B. Posttransplant lymphoproliferative disease after pediatric solid organ transplantation. Clin Dev Immunol 2013; 2013: 814973.

139. Nampoory MR, Khan ZU, Johny KV, Constandi JN, Gupta RK, Al-Muzairi I, Samhan M, Mozavi M, Chugh TD. Invasive fungal infections in renal transplant recipients. J Infect 1996; 33: 95-101.

140. Nankivell BJ, Lau SG, Chapman JR, O'Connell PJ, Fletcher JP, Allen RD. Progression of macrovascular disease after transplantation. Transplantation 2000; 69: 574-581. 
141. Nasser SA, Elmallah Al, Sabra R, Khedr MM, El-Din MM, El-Mas MM. Blockade of endothelin ET(A), but not thromboxane, receptors offsets the cyclosporine-evoked hypertension and interrelated baroreflex and vascular dysfunctions. Eur J Pharmacol 2014; 727: 52-59.

142. Nichols RA, Suplick GR, Brown JM. Calcineurin-mediated protein dephosphorylation in brain nerve terminals regulates the release of glutamate. J Biol Chem 1994; 269: 23817-23823.

143. Nishiguchi T, Mochizuki K, Shakudo M, Takeshita T, Hino M, Inoue Y. CNS Complications of Hematopoietic Stem Cell Transplantation. AJR 2009; 192: 1003-1011.

144. Oliveras A, Roquer J, Puig JM, Rodríguez A, Mir M, Orfila MA, Masramon J, Lloveras J. Stroke in renal transplant recipients: epidemiology, predictive risk factors and outcome. Clin Transplant 2003; 17: 1-8.

145. Opelz G, Döhler B; Collaborative Transplant Study. Influence of immunosuppressive regimens on graft survival and secondary outcomes after kidney transplantation. Transplantation 2009. 87: 795-802.

146. Ozdemir FN, Akgul A, Altunoglu A, Bilgic A, Arat Z, Haberal M. The association between cytomegalovirus infection and atherosclerotic events in renal transplant recipients. Transplant Proc 2007; 39: 990-992.

147. Papachristou E, Papadimitropoulos A, Kotsantis P, Goumenos DS, Katsoris PG, Vlachojannis JG. Cyclosporine induces endothelin-1 mRNA synthesis and nitric oxide production in human proxima tubular epithelial cell cultures. Ren Fail 2009; 31: 372-376.

148. Pappas PG, Alexander BD, Andes DR, Hadley S, Kauffman CA, Freifeld A, Anaissie EJ, Brumble LM, Herwaldt L, Ito J, Kontoyiannis DP, Lyon GM, Marr KA, Morrison VA, Park BJ, Patterson TF, Perl TM, Oster RA, Schuster MG, Walker R, Walsh TJ, Wannemuehler KA, Chiller TM. Invasive fungal infections among organ transplant recipients: results of the Transplant-Associated Infection Surveillance Network (TRANSNET). Clin Infect Dis 2010; 50: 1101-1111.

149. Parvex P, Pinsk M, Bell LE, O'Gorman AM, Patenoude YG, Gupta IR. Reversible encephalopathy associated with tacrolimus in pediatric renal transplant. Pediatr Nephrol 2001; 16: 537-542.

150. Patchell RA. Neurological complications of organ transplantation. Ann Neurol 1994; 36: 688-703.

151. Paya CV, Fung JJ, Nalesnik MA, Kieff E, Green M, Gores G, Habermann TM, Wiesner PH, Swinnen JL, Woodle ES, Bromberg JS. EBV-induced posttransplant lymphoproliferative disorders. ASTS/ASTP EBV PTLD Task Force and the Mayo Clinic Organized International Consensus Development Meeting. Transplantation 1999; 68: 1517-1525.

152. Penn I. Posttransplant malignancies. Transplant Proc 1999; 31: 1260-1262.

153. Penn I. Some problems with posttransplant lymphoproliferative disease. Transplantation 2000; 79: 705

154. Pescovitz MD, Govani M. Sirolimus and mycophenolate mofetil for calcineurin-free immunosuppression in renal transplant recipients. Am J Kidney Dis 2001; 38 (4 Suppl 2): S16-21.

155. Pickhardt PJ, Siegel MJ, Hayashi RJ, Kelly M. Posttransplantation lymphoproliferative disorder in children: clinical, histopathologic and imaging features. Radiology 2000; 217: 16-25.
156. Pinho de Oliveira Ribeiro N, Rafael de Mello Schier A, Ornelas AC, Pinho de Oliveira CM, Nardi AE, Silva AC. Anxiety, depression and suicidal ideation in patients with rheumatoid arthritis in use of methotrexate, hydroxychloroquine, leflunomide and biological drugs. Compr Psychiatry 2013; 54: 1185-1189.

157. Pirsch JD, Miller J, Deierhoi MH, Vincenti F, Filo RS. A comparison of tacrolimus and cyclosporine for immunosuppression after cadaveric renal transplantation. Kidney transplant Study Group. Transplantation 1997; 63: 977.

158. Plata-Munoz JJ, Vaidya A, Fuggle SV, Friend PJ. Effect of alemtuzumab or basiliximab induction therapy on graft function and survival of kidneys from donors after cardiac death. Transpl Int 2009; 22: 1024-1027.

159. Polskie Towarzystwo Transplantacyjne, Zalecenia Dotyczące Leczenia Immunosupresyjnego Po Przeszczepieniu Narządów Unaczynionych. In: Durlik M, Zieniewicz K (ed). Fundacja Zjednoczeni dla Transplantacji, Warszawa, 2016. https://p-t-t.org/ index.php/content/download/8785/128648/file/Zalecenia immunopresyjne_2016.pdf.

160. Ponticelli C, Campise MR. Neurological complications in kidney transplant recipients. J Nephrol 2005; 18: 521-528.

161. Pontin AR, Donaldson RA, Jacobson JE. Femoral neuropathy after renal transplantation. S Afr Med J 1978; 53: 376-378.

162. Qin W, Tan CY, Huang X, Huang Z, Tao Y, Fu P. Rapamycin-induced posterior reversible encephalopathy in a kidney transplantation patient. Int Urol Nephrol 2011; 43: 913-916.

163. Qiu Y, Wang X, Fan J, Rao Z, Lu Y, Lin T. Conversion From Calcineurin Inhibitors to Mammalian Target-of-Rapamycin Inhibitors in Heart Transplant Recipients: A Meta-Analysis of Randomized Controlled Trials. Transplant Proc 2015; 47: 2952-2956.

164. Reinohs M, Straube T, Baum P, Berrouschot J, Wagner A. Recurrent reversible cerebral edema after long term immunosuppression with tacrolimus. J Neurol 2002; 249: 780-781.

165. Renard D, Gauthier T, Venetz JP, Buclin T, Kuntzer T. Late onset tacrolimus-induced life-threatening polyneuropathy in a kidney transplant recipient patient. Clin Kidney J 2012; 5: 323-326.

166. Resener M, Martin E, Zipp F, Dichgans J, Martin R. Neurological side-effects of pharmacologic corticoid therapy. Neverarzt 1996; 67: 983.

167. Reul JM, de Kloet ER. Two receptor systems for corticosterone in rat brain: microdistribution and differential occupation. Endocrinology 1985; 117: 2505-2511.

168. Reyes J, Gayowski T, Fung J, Todo S, Alessiani M, Starzl TE. Expressive dysphasia possibly related to FK506 in two liver transplant recipients. Transplantation 1990; 50: 1043-1045.

169. Rituximab, Summary of Product Characteristics 2008, http:// www.ema.europa.eu/docs/en_GB/document_library/EPAR_Product_Information/human/000165/ WC500025821.pdf.

170. Rodrigues-Diez R, González-Guerrero C, Ocaña-Salceda C, Rodrigues-Diez RR, Egido J, Ortiz A, Ruiz-Ortega M, Ramos AM. Calcineurin inhibitors cyclosporine $A$ and tacrolimus induce vascular inflammation and endothelial activation through TLR4 signaling. Sci Rep 2016; 6: 27915.

171. Rowe I, Neuberger JM. Pharmacology of transplantation. In: Primer on Transplantation. Hricik D (ed.). 3rd ed. Wiley-Blackwell, American Society of Transplantation 2011. 
172. Sahutoglu T, Akgul SU, Caliskan Y, Yazici H, Demir E, Kara E, Temurhan S, Savran FO, Turkmen A. Tac-MMF Versus CSAMMF/CSA-AZA-Based Regimens in Development of De Novo Complement-Binding Anti-HLA Antibodies After Kidney Transplantation. Transplant Proc 2017; 49: 454-459.

173. Salzberg DJ, Karadsheh FF, Haririan A, Reddivari V, Weir MR. Specific management of anemia and hypertension in renal transplant recipients: influence of renin-angiotensin system blockade. Am J Nephrol 2014; 39: 1-7.

174. Satterthwaite R, Aswad S, Sunga V, Shidban H, Bogaard T, Asai P, Khetan U, Akra I, Mendez RG, Mendez R. Incidence of new-onset hypercholesterolemia in renal transplant patients treated with FK506 or cyclosporine. Transplantation 1998; 65: 446-449.

175. Schacherer D, Zeitoun M, Buttner R, Gelbmann C, Obed A, Schlitt HJ, Scholmerich J, Kirchner GI. Sirolimus-induced drug fever and ciclosporin-induced leukencephalopathia with seizures in one liver transplant recipient. World J Gastroenterol 2007; 13: 6090-6093.

176. Schiff D, Wen PY, van den Bent MJ. Neurological adverse effects caused by cytotoxic and targeted therapies. Nat Rev Clin Oncol 2009; 6: 596-603.

177. Senzolo M, Ferronato C, Burra P. Neurologic complications after solid organ transplantation. Transpl Int 2009; 22: 269-278.

178. Serkova N, Jacobsen W, Niemann CU, Litt L, Benet LZ, Leibfritz D, Christians U. Sirolimus, but not the structurally related RAD (everolimus), enhances the negative effects of cyclosporine on mitochondrial metabolism in the rat brain. Br J Pharmacol 2001; 133: 875-885.

179. Serkova N, Litt L, Leibfritz D, Hausen B, Morris RE, James TL, Benet LZ, Christians U. The novel immunosuppressant SDZ-RAD protects rat brain slices from cyclosporine-induced reduction of high-energy phosphates. Br J Pharmacol 2000; 129: 485-492.

180. Serkova NJ, Christians U, Benet LZ. Biochemical Mechanisms of Cyclosporine Neurotoxicity. Mol Interv 2004; 4: 97-107.

181. Sharma KR, Cross J, Santiago F, Ayyar DR, Burke G. Incidence of acute femoral neuropathy following renal transplant. Arch Neurol 2002; 59: 541-545.

182. Shbarou RM, Chao NJ, Morgenlander JC. Cyclosporin A-related cerebral vasculopathy. Bone Marrow Transplant 2000; 26: 801-804.

183. Sheridan PH Jr, Cheriyan A, Doud J, Dornseif SE, Montoya A, Houck J, Flisak ME, Walsh JM, Garrity ER Jr. Incidence of phrenic neuropathy after isolated lung transplantation. J Heart Lung Transplant 1995; 14: 684-691.

184. Shoham S, Marr KA. Invasive fungal infections in solid organ transplant recipients. Future Microbiol 2012; 7: 639-655.

185. Sihra TS, Nairn AC, Kloppenburg P, Lin Z, Pouzat C. A role for calcineurin (protein phosphatase-2B) in the regulation of glutamate release. Biochem Biophys Res Commun 1995; 212: 609-616.

186. Simha V, Qin S, Shah P, Smith BH, Kremers WK, Kushwaha S, Wang L, Pereira NL. Sirolimus Therapy Is Associated with Elevation in Circulating PCSK9 Levels in Cardiac Transplant Patients. J Cardiovasc Transl Res 2017; 10: 9-15.

187. Singh N, Alexander BD, Lortholary O, Dromer F, Gupta KL, John GT, del Busto R, Klintmalm GB, Somani J, Lyon GM, Pursell K, Sto- sor V, Munoz P, Limaye AP, Kalil AC, Pruett TL, Garcia-Diaz J, Humar A, Houston S, House AA, Wray D, Orloff S, Dowdy LA, Fisher RA, Heitman J, Wagener MM, Husain S; Cryptococcal Collaborative Transplant Study Group. Cryptococcus neoformans in organ transplant recipients: impact of calcineurininhibitor agents on mortality. J Infect Dis 2007; 195: 756-764.

188. Singh N, Lortholary O, Dromer F, Alexander BD, Gupta KL, John GT, del Busto R, Klintmalm GB, Somani J, Lyon GM, Pursell K, Stosor V, Munoz P, Limaye AP, Kalil AC, Pruett TL, Garcia-Diaz J, Humar A, Houston S, House AA, Wray D, Orloff S, Dowdy LA, Fisher RA, Heitman J, Wagener MM, Husain S; Cryptococcal Collaborative Transplant Study Group. Central nervous system cryptococcosis in solid organ transplant recipients: clinical relevance of abnormal neuroimaging findings. Transplantation 2008; 86: 647-651.

189. Skelton SL, Waterman AD, Davis LA, Peipert JD, Fish AF. Applying best practices to designing patient education for patients with end-stage renal disease pursuing kidney transplant. Prog Transplant 2015; 25: 77-84.

190.Sklar EM. Post-transplant neurotoxicity: what role do calcineurin inhibitors actually play? AJNR Am J Neuroradiol 2006; 27: 1602-1603.

191. Small SL, Fukui MB, Bramblett GT, Eidelman BH. Immunosuppression-induced leukoencephalopathy from tacrolimus (FK506). Ann Neurol 1996; 40: 575-580.

192. Smith JA. CNS Infections in Solid Organ Transplant Recipients. In: Hospital Physician Neurology Board Review Manual. Gallagher C (ed.). Turner White Communications, Inc., Wayne 2005; 2-15.

193. Srinivas TR, Meier-Kriesche HU. Minimizing immunosuppression, an alternative approach to reducing side effects: objectives and interim result. Clin J Am Soc Nephrol 2008; 3 Suppl 2: S101-S116.

194. Stracciari A, Guarino M. Neuropsychiatric complications of liver transplantation. Metab Brain Dis 2001; 16: 3.

195. Tedesco D, Haragsim L Cyclosporine: a review. J Transplant 2012; 2012: 230386.

196. Tezcan H, Zimmer W, Fenstermaker R, Herzig GP, Schriber J. Severe cerebellar swelling and thrombotic thrombocytopenic purpura associated with FK506. Bone Marrow Transplant 1998; 21: 105-109.

197. Thistlethwaite JR Jr, Stuart JK, Mayes JT, Gaber AO, Woodle S, Buckingham MR, Stuart FP. Complications and monitoring of OKT3 therapy. Am J Kid Dis 1988; 11: 112-119.

198. Thorp M, DeMattos A, Bennett W, Barry J, Norman D. The effect of conversion from cyclosporine to tacrolimus on gingival hyperplasia, hirsutism and cholesterol. Transplantation 2000; 69: 1218-1220.

199. Thymoglobuline Summary of Product Characteristics, 2016; http://www.medicines.org.uk/emc/medicine/20799/SPC.

200. Tolou-Ghamari Z, Mortazavi M, Palizban A-A, Najafi M-R. The investigation of correlation between Iminoral concentration and neurotoxic levels after kidney transplantation. Adv Biomed Res 2015; 4: 59.

201. Torre-Cisneros J, Lopez OL, Kusne S, Martinez AJ, Starzl TE, Simmons RL, Martin M. CNS aspergillosis in organ transplanta- 
tion: a clinicopathological study. J Neurol Neurosurg Psychiatry 1993; 56: 188-193.

202. Touhami S, Arzouk N, Darugar A, Heron E, Clarençon F, Bodaghi B, LeHoang P, Barrou B, Touitou V. Everolimus-induced posterior reversible encephalopathy syndrome and bilateral optic neuropathy after kidney transplantation. Transplantation 2014; 98: e102-104.

203. Truwit CL, Denaro CP, Lake JR, DeMarco T. MRI imaging of reversible cyclosporine A-induced neurotoxicity. AJNR Am J Neuroradiol 1991; 12: 651-659.

204. Trzepacz PT, Levenson JL, Tringali RA. Psychopharmacology and neuropsychiatric syndromes in organ transplantation. Gen Hosp Psychiatry 1991; 13: 233-245.

205. U.S. Multicenter FK506 Liver Study Group. A comparison of tacrolimus (FK 506) and cyclosporine for immunosuppression in liver transplantation. N Engl J Med 1994; 331: 1110-1115.

206. Uhr M, Holsboer F, Müller MB. Penetration of endogenous steroid hormones corticosterone, cortisol, aldosterone and progesterone into the brain is enhanced in mice deficient for both mdr1a and mdr1b P-glycoproteins. J Neuroendocrinol 2002; 14: 753-759.

207. United States Renal Data System (USRDS), annual data report; www.usrds.org.

208. van Balkom RH, van der Heijden HF, van Herwaarden CL, Dekhuijzen PN. Corticosteroid-induced myopathy of the respiratory muscles. Neth J Med 1994; 45: 114-122.

209. van der Hoeven J, Duyx J, de Langen JJ, van Royen A. Probable psychiatric side effects of azathioprine. Psychosom Med 2005; 67: 508.

210. van Sandwijk MS, Bemelman FJ, Ten Berge IJ. Immunosuppres sive drugs after solid organ transplantation. Neth J Med 2013; 71: 281-289.

211. van Veen KE, Brouwer MC, van der Ende A, van de Beek D. Bacterial meningitis in solid organ transplant recipients: a population-based prospective study. Transpl Infect Dis 2016; 18: 674-680.

212. Van Veer H, Coosemans W, Pirenne J, Monbaliu D. Acute femoral neuropathy: a rare complication after renal transplantation. Transplant Proc 2010; 42: 4384-4388.

213. Victor RG, Thomas GD, Marban E, O'Rourke B. Presynaptic modulation of cortical synaptic activity by calcineurin. Proc Natl Acad Sci 1995; 92: 6269-6273.

214. Viswanathan R, Glickman L. Clonazepam in the treatment of steroid-induced mania in a patient after renal transplantation. N Engl J Med 1989; 320: 319-320.

215. Wagner M, Earley AK, Webster AC, Schmid CH, Balk EM, Uhlig K. Mycophenolic acid versus azathioprine as primary immunosuppression for kidney transplant recipients. Cochrane Database Syst Rev 2015; 12: CD007746.

216. Waiser J, Duerr M, Budde K, Rudolph B, Wu K, Bachmann F, Halleck F, Schönemann C, Lachmann N. Treatment of Acute Antibody-Mediated Renal Allograft Rejection with Cyclophosphamide. Transplantation 2016; Dec 22; doi: 10.1097/TP. 0000000000001617.

217. Weick A, Chacra W, Kuchipudi A, Elbatta M, Divine G, Burmeister C, Moonka D. Incidence of cardiovascular and cerebrovas- cular events associated with sirolimus use after liver transplantation. Transplant Proc 2015; 47: 460-464.

218. West S, Kenedi C. Strategies to prevent the neuropsychiatric side effects of corticosteroids: a case report and review of the literature. Curr Opin Organ Transplant 2014; 19: 201-208.

219. Wijdicks EF, Torres VE, Schievink WI, Sterioff S. Cerebral hemorrhage in recipients of renal transplantation. Mayo Clin Proc 1999; 74: 1111-1112.

220. Wijdicks EF, Wiesner RH, Dahlke LJ, Krom RA. FK-506-induced neurotoxicity in liver transplantation. Ann Neurol 1994; 35 : 498-501.

221. Wijdicks EF. Neurotoxicity of immunosuppressive drugs. Liver Transpl 2001; 7: 937-942.

222. Wijdicks EFM, Dahlke L, Wiesner RH. Oral cyclosporine decreases severity of neurotoxicity in liver transplant recipients. Neurology 1999; 52: 1708-1710.

223. Wijdicks EFM, Wiesner RH, Krom RAF. Neurotoxicity in liver transplant patients with cyclosporine immunosuppression. Neurology 1995; 45: 1962-1964.

224. Wilson JR, Conwit RA, Eidelman BH, Starzl T, Abu-Elmagd K. Sensorimotor neuropathy resembling CIDP in patients receiving FK506. Muscle Nerve 1994; 17: 528-532.

225. Wing MG, Moreau T, Greenwood J, Smith RM, Hale G, Isaacs J, Waldmann H, Lachmann PJ, Compston A. Mechanism of firstdose cytokine-release syndrome by CAMPATH $1-\mathrm{H}$ : involvement of CD16 (FcgammaRIII) and CD11a/CD18 (LFA-1) on NK cells. J Clin Invest 1996; 98: 2819-2826.

226. Wise MG, Brannan SK, Shanfield SB, Moeller FG. Psychiatric aspects of organ transplantation. JAMA 1988; 260: 3437.

227. Wiseman AC. Immunosuppressive Medications. Clin J Am Soc Nephrol 2016; 11: 332-343.

228. Wiseman AC. Induction Therapy in Renal Transplantation: Why? What Agent? What Dose? We May Never Know. Clin J Am Soc Nephrol 2015; 10: 923-925.

229. Working Party of The British Transplant Society, Guidelines for Antibody Incompatible Transplantation. 3rd Edition, 2015; https://bts.org.uk/wp-content/uploads/2016/09/02_BTS_Antibody_Guidelines-1.pdf (Access 21.05.2017).

230. Wright AJ, Fishman JA. Central nervous system syndromes in solid organ transplant recipients. Clin Infect Dis 2014; 59: 1001-1011.

231. Wszolek ZK, Steg RE. Seizures after liver transplantation. Liver Transplant Surg 1995; 1: 334-339.

232. Wu G, Vilchez RA, Eidelman B, Fung J, Kormos R, Kusne S. Cryptococcal meningitis: an analysis among 5,521 consecutive organ transplant recipients. Transpl Infect Dis 2002; 4: 183-188.

233. Wu G, Weng FL, Balaraman V. Tacrolimus-induced encephalopathy and polyneuropathy in a renal transplant recipient. BMJ Case Rep 2013; pii: bcr2013201099.

234. Xie X, Jiang Y, Lai X, Xiang S, Shou Z, Chen J. mTOR inhibitor versus mycophenolic acid as the primary immunosuppression regime combined with calcineurin inhibitor for kidney transplant recipients: a meta-analysis. BMC Nephrol 2015; 16: 91.

235. Yakel JL. Calcineurin regulation of synaptic function: from ion channels to transmitter release and gene transcription. Trends Pharmacol Sci 1997; 18: 124-134. 
236. Yamamoto T, Watarai Y, Futamura K, Okada M, Tsujita M, Hiramitsu T, Goto N, Narumi S, Takeda A, Kobayashi T. Efficacy of Eculizumab Therapy for Atypical Hemolytic Uremic Syndrome Recurrence and Antibody-Mediated Rejection Progress After Renal Transplantation With Preformed Donor-Specific Antibodies: Case Report. Transplant Proc 2017; 49: 159-162.

237. Yu JJ, Zhang Y, Wang Y, Wen ZY, Liu XH, Qin J, Yang JL Inhibition of calcineurin in the prefrontal cortex induced depressive-like behavior through mTOR signaling pathway. Psychopharmacology (Berl) 2013; 225: 361-72.

238. Zheng JP, Cheng Z, Jiang J, Ke Y, Liu Z. Cyclosporin A upregulates ETB receptor in vascular smooth muscle via activation of mitogen-activating protein kinases and NF-KB pathways. Toxicol Lett 2015; 235: 1-7.

239. Zheng XF, Florentino D, Chen J, Crabtree GR, Schreiber SL. TOR kinase domains are required for two distinct functions, only one of which is inhibited by rapamycin. Cell 1995; 82: 121-130.

240. Zilinska Z, Sersenova M, Chrastina M, Breza J Sr, Bena L, Baltesova T, Jurcina A, Roland R, Lackova E, Cellar M, Laca L, Dedinska I. Occurrence of malignancies after kidney transplantation in adults: Slovak multicenter experience. Neoplasma 2017; 64: 311-317.

241. Zunt JR. Central nervous system infection during immunosuppression. Neurol Clin 2002; 20: 1-22. 